\title{
From nummi minimi to fulūs_-small change and wider issues: characterising coinage from Gerasa/Jerash (Late Roman to Umayyad periods)
}

\author{
Thomas Birch $^{1,2}$ (1) $\cdot$ Vana Orfanou $^{1,2,3} \cdot$ Achim Lichtenberger $^{4} \cdot$ Rubina Raja $^{1,5} \cdot$ Gry Barfod $^{1,2,3} \cdot$ Charles E. Lesher $^{1,2,3}$. \\ Ingrid Schulze ${ }^{6} \cdot$ Wolfgang Schulze ${ }^{6}$
}

Received: 11 September 2018 / Accepted: 13 May 2019 / Published online: 25 June 2019

(C) The Author(s) 2019

\begin{abstract}
New compositional and metallographic data are presented for the fourth to eighth century CE copper coins from the Northwest Quarter of Gerasa/Jerash, Jordan. The majority of the coins are small copper and copper alloy nummi minimi from the Late Roman and Byzantine periods. Also represented are pre-reform and post-reform fulūs minted under the Umayyad dynasty. Seventy-one coins (55 Roman, 4 Byzantine, 3 pre-reform and 9 post-reform) were characterised using optical microscopy and micro-X-ray fluorescence $(\mu-\mathrm{XRF})$ spectroscopy. Lead $(\mathrm{Pb})$ isotopes were measured for a subset of coins. We find that all coins were cast as flans before striking and that there is a discernible increase in alloying and debasement of copper during the fifth century $\mathrm{CE}$ and end of the seventh century $\mathrm{CE}$. The $\mathrm{Pb}$ isotope results suggest the use of copper metal from the Aegean and the Arabah, and lead metal from Western Europe. The temporal changes in the alloy composition suggest periods of optimisation in the use of raw materials whilst maintaining a continuity in the technology used in minting coinage, perhaps related to broader economic and monetary issues associated with the fifth century CE and the coin reform of "Abd al-Malik.
\end{abstract}

Keywords Nummi minimi $\cdot$ Fulūs $\cdot$ Gerasa $\cdot$ Jerash $\cdot$ Coins $\cdot$ Lead isotope analysis $\cdot$ XRF $\cdot$ Roman $\cdot$ Byzantine $\cdot$ Umayyad

\section{Introduction}

Just over 800 copper-based coins were recovered from excavations of the ancient city of Gerasa (Jerash today) in Jordan during the Danish-German Jerash Northwest Quarter Project. These coins date mostly from the
Roman to the Early Islamic Periods (Schulze and Schulze 2018) and represent a unique opportunity to research daily coinage in a region not sufficiently studied compared to their counterparts (i.e. nummi minimi) in the Western Roman Empire (cf. Canovaro et al. 2013, 2015; Scuotto et al. 2014).

Electronic supplementary material The online version of this article (https://doi.org/10.1007/s12520-019-00866-9) contains supplementary material, which is available to authorized users.

Thomas Birch

t.birch@cas.au.dk

1 Centre for Urban Network Evolutions (UrbNet), Aarhus University, Moesgaard Allé 20, 4230, 2nd floor, Højbjerg, DK-8270 Aarhus, Denmark

2 Aarhus Geochemistry and Isotope Research (AGIR) Platform, Aarhus University, Høegh-Guldbergs Gade 2, 1670-1675, DK-8000 Aarhus C, Denmark
3 Department of Geoscience, Aarhus University, Høegh-Guldbergs Gade 2, DK-8000 Aarhus C, Denmark

4 Institut für Klassische Archäologie und Christliche Archäologie/ Archäologisches Museum, Westfälische Wilhelms-Universität Münster, Domplatz 20-22, D-48143 Münster, Germany

5 Department of Classical Archaeology, Aarhus University, Jens Christian Skous Vej 5, 1461, DK-8000 Aarhus C, Denmark

6 Independent scholars, Essen, Germany 
Through a diachronic study characterising the composition and technology of copper-based coins from the 4th to 8th centuries CE, this paper seeks to identify continuity and change of everyday coinage in Gerasa/Jerash. The new results presented here contribute significantly to our understanding of coinage in the Eastern Mediterranean, comparatively less studied than the Western Mediterranean. This paper presents tangible results relating to the 'monetary crisis' of the fifth century $\mathrm{CE}$ as well as the coin reform of 'Abd al-Malik. Together, they provide a diachronic insight into the composition of the metal(s) used for copper coinage as well as minting technology. The results also include the first lead $(\mathrm{Pb})$ isotope analyses of nummi minimi and fulūs, used to investigate the origins of the metals used in coin production. This study has broader implications for our understanding of metals used in Late Antiquity in the Eastern Mediterranean.

\section{The archaeological context}

Gerasa/Jerash was a Greco-Roman city founded in the Hellenistic period. During the first and second centuries CE urban expansion took place and the city thrived throughout the Roman, Late Roman, Byzantine and Early Islamic periods. Gerasa/Jerash was nearly completely abandoned following the earthquake of 749 CE (Kraeling 1938; Lichtenberger and Raja 2018). Gerasa/Jerash has undergone archaeological investigations for more than a century focused mainly on public monuments along the main and side streets in the western half of the city. The Danish-German Jerash Northwest Quarter project from 2011 investigated the settlement history in the area northwest of the Roman period Artemision (see Fig. 1). The Northwest Quarter is the highest area within the walled city (Lichtenberger and Raja 2017) and was most intensively occupied during the Late Roman to Umayyad periods. Several domestic, industrial and religious complexes from these periods were excavated during the Danish-German Jerash Northwest Quarter project, and the coinage for this study come from these excavations.

\section{Daily small change}

Copper coinage was essential for everyday use. Like today, small change was needed to facilitate transactions in daily urban life during the Roman, Byzantine and Islamic periods (Treadwell 2015, p. 79; Bijovsky 2017, p. 180). Here, we focus on two denominations, i.e. Late Roman/Byzantine nummi minimi and Umayyad fulūs. Although the Latin nummus (plural nummi) refers to 'coin' generally, it was also used to refer to the follis bronze coins introduced at the end of the third century CE, and thereafter a name for tiny bronze coins being minted in the fifth century $\mathrm{CE}$ and in various denominations thereafter (i.e. a 5 or 40 nummi coin) through until 775-842 CE (Klose 2006). In the early Byzantine period, a 'nummus', "applied to the smallest copper coin", worth $1 / 40$ of the follis (Grierson 1999, p. 58). The nummus is the small denomination $Æ 4$ and here is considered the same as a 'minimus', a description owing to its small size, which is often considered to be manufactured from poorer standard metal (Bijovsky 2000; Baldi 2014). We deliberately refer to the $\approx 1 \mathrm{~g}$ copper-based coinage as nummi minimi (plural), to reflect how both nummi and minimi are terms that have been used interchangeably to refer to the same coins, though some scholars make a distinction between 'nummus', 'nummi' and 'minimi' (cf. Hohlfelder 1973, p. 90; Grierson 1999, p. 18; Bijovsky 2000, 2012).

Bijovsky $(2000,2012)$ provides the most comprehensive archaeological and numismatic overview of currency during the fifth century CE in the region. Many of the coin finds from this period are nummi minimi by our definition. The predominance of fourth and fifth century coinage in the region has also been reported by Kind et al. (2005, p. 180). These authors report that about half $(51 \%)$ of the 3119 coins at Caesarea Maritima are dated to the fourth and fifth centuries CE, with a similar relative proportion of the total coins $(57.7 \%)$ so far published for the fourth $(42.8 \%)$ and fifth $(14.9 \%)$ centuries $\mathrm{CE}$ for Gerasa/Jerash. These figures show that at both sites, nummi minimi represent a significant portion of the total coinage found, indicating its importance in daily transactions during this time. Currently, very few compositional studies have been conducted on these small, often unidentifiable lumps, which this paper seeks to address.

\section{The coin finds}

Table 1 presents a list of excavated coin finds from the Northwest Quarter. Of these, 132 of the excavated coins were found in Umayyad buildings, which were destroyed during the earthquake of 749 CE (Schulze and Schulze 2018). Old Roman coins, Roman and Byzantine minimi, and foreign coppers formed an important part of the money circulating parallel to the pre- and post-reform fuluss up to the end of Umayyad rule. The 455 minimi represent $56.7 \%$ of the total coin finds from the Northwest Quarter, comparable to the relative proportions previously stated for Caesarea Maritima and Gerasa/ Jerash. The identification of the coins analysed in this study are given in Table 2.

The excavations also yielded copper coinage of the first Islamic Caliphates. These pre-reform fulūs developed from simple imitations of Byzantine coins (Phase 1) over coins with Greek and/or Arabic inscriptions (Phase 2) up to the so called Standing Caliph coinage (Phase 3 ) before being reformed under 'Abd al-Malik (685-705 CE) of the Umayyad dynasty to become characteristic for the Islamic coinage. Some scholars 


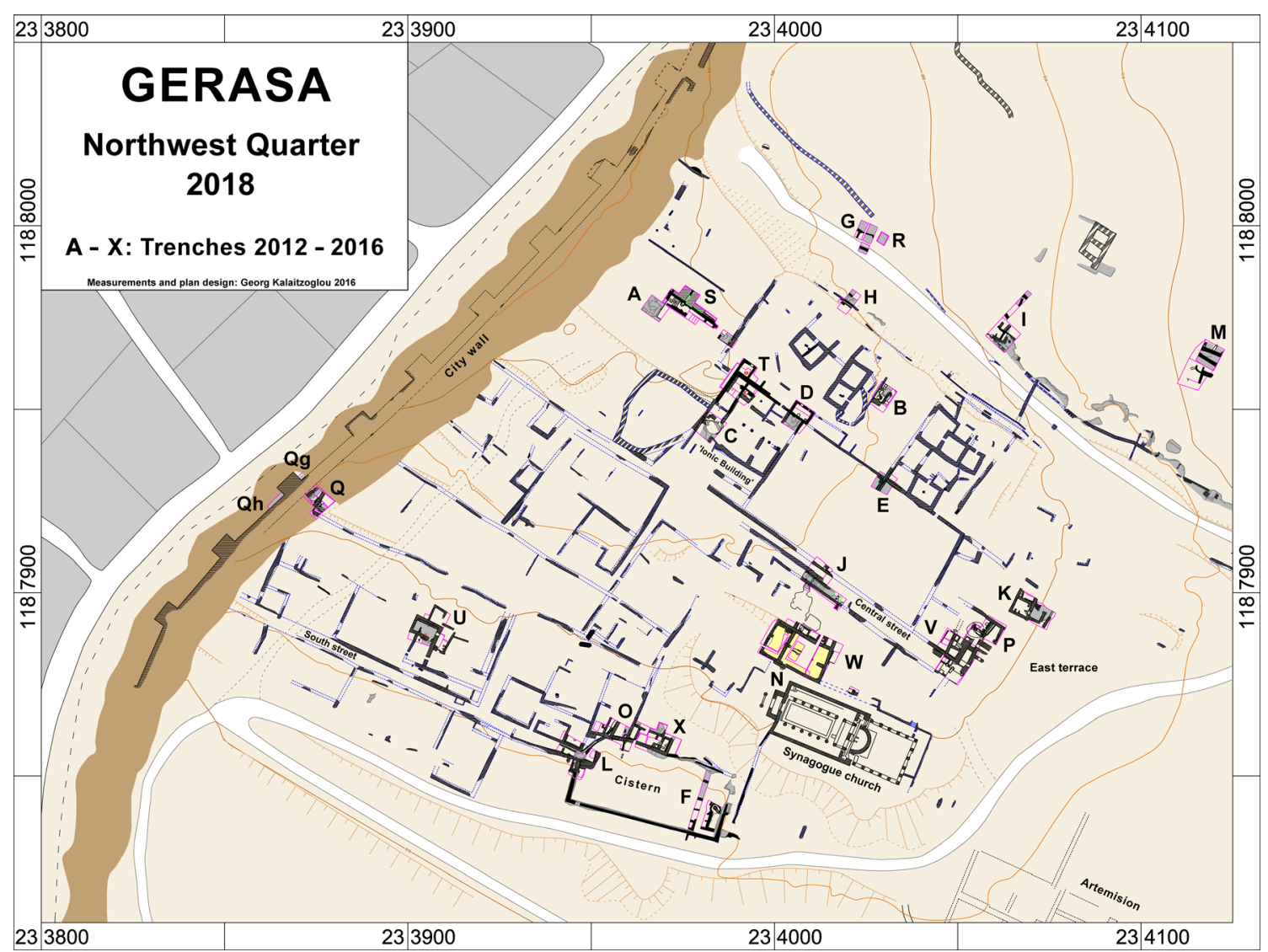

Fig. 1 Plan of the Northwest Quarter of Jerash (Danish-German Jerash Northwest Quarter Project)

consider Umayyad copper coins to be a bullion currency (rather than token currency) (Schindel 2006, p. 388); nonetheless, they are still recognisably important for facilitating daily transactions.

Of the 71 coins selected for this study, 59 are nummi minimi and 12 are fulūs. These coins are considered representative of both denominations and are in a good state of preservation based on outward appearance (see examples in Fig. 2; images of all coins are included in the supplementary material S1). As we show, these denominations share, broadly speaking, the same metals and, thus we surmise, served the same economic function.

Weights and diameters of the Roman/Byzantine nummi minimi are summarised in Fig. 3. Note that some of the small diameters and weights are due to poor preservation or being fragmented. The mean weight of 274 nummi minimi from the Northwest Quarter excavations is $0.79 \pm 0.39 \mathrm{~g}$ (median = $0.76 \mathrm{~g}$, potentially referring to the most frequent weight denomination), with a mean diameter of $10.6 \pm 1.9 \mathrm{~mm}$ (same as the median, the most frequent diameter measured).

\section{Analytical methods}

The coins were analysed for their chemical composition, microstructure and hardness. The edge of each coin was sliced off using a jeweller's saw. Samples were mounted in epoxyresin, ground flat and polished to a $0.25-\mu \mathrm{m}$ finish. Metal composition was determined using a Bruker M4 TORNADO micro-XRF spectrometer. Microstructures were examined in unetched mounts by reflected light optical microscopy (Nikon Eclipse E600 POL). Vickers (VH) hardness was determined using a diamond pyramid indentor mounted on a Zwick/Roell ZHU250top hardness testing machine. The $\mathrm{Pb}$ isotope composition of a subset of coins was determined using standard chromatographic methods and analysis by multi-collector inductively coupled plasma mass spectrometry (MC-ICP-MS) (Durali-Mueller et al. 2007; Klein et al. 2009). Details of our XRF methods, Vickers hardness measurements and $\mathrm{Pb}$ isotope analysis are provided as supplementary material (S2).

\section{Results}

An overview of the nummi minimi analytical results are provided initially before detailing the chronological changes in coin compositions by century, finishing with fulūs. The full results are provided in Table 3. Although the results are somewhat limited by the broad date ranges of the coins, some 
Table 1 List of coin finds excavated from the Northwest Quarter Gerasa/Jerash

\begin{tabular}{|c|c|c|}
\hline \multicolumn{2}{|l|}{ Type } & Coun \\
\hline \multicolumn{2}{|l|}{ Hellenistic (2nd century BCE) } & 1 \\
\hline \multicolumn{2}{|l|}{ Judaean (1st century CE) } & 2 \\
\hline \multicolumn{2}{|l|}{ Nabataean (1st century CE) } & 2 \\
\hline \multicolumn{2}{|c|}{ Roman Imperial (2nd and 4th centuries CE) } & 2 \\
\hline \multicolumn{2}{|l|}{$\begin{array}{l}\text { Roman Provincial } \\
\text { (2nd and 3rd centuries CE) }\end{array}$} & 12 \\
\hline \multirow[t]{3}{*}{ Late Roman (4th and 5th centuries): } & Large coppers & 45 \\
\hline & Æ3 & 57 \\
\hline & Minimi (Æ4) & 214 \\
\hline \multicolumn{2}{|l|}{$\begin{array}{l}\text { Late Roman Minimi not closer } \\
\text { attributed (possibly including } \\
\text { some early Byzantine) }\end{array}$} & 241 \\
\hline \multirow[t]{2}{*}{ Byzantine up to Constans II } & Various denominations & 45 \\
\hline & Minimus & 1 \\
\hline \multicolumn{2}{|l|}{$\begin{array}{l}\text { Umayyad Pre-Reform } \\
\text { (c. 639-c. } 697 \text { CE) }\end{array}$} & 12 \\
\hline \multicolumn{2}{|l|}{$\begin{array}{l}\text { Umayyad Post-Reform } \\
\text { (c. } 697-\text { c. } 749 \text { CE) }\end{array}$} & 53 \\
\hline \multicolumn{2}{|l|}{ Abbasid } & - \\
\hline \multicolumn{2}{|l|}{ Ayyubid (12th/13th century CE) } & 2 \\
\hline \multicolumn{2}{|l|}{ Mamluk } & - \\
\hline \multicolumn{2}{|l|}{ Not identified } & 13 \\
\hline \multicolumn{2}{|l|}{ Not coins } & 11 \\
\hline & Total & 803 \\
\hline
\end{tabular}

general observations can be made related to chronological developments in metal compositions.

\section{Coin microstructures}

The microstructures of all the coins, both the Roman/ Byzantine nummi minimi and Umayyad fulüs, show that they were cast to shape (cast flans) before striking (the images and legends being pressed into the cast flans using a hammer and die). The cross-sections of the copper alloys show typical dendritic microstructures from the original casting. Many of the coins also exhibit a preferential dendrite direction, indicating that the cast microstructure was partially flattened from when the cast flans were struck to thickness (which could have been performed whilst the flan was still hot), such as that shown in Fig. 4. The preferential grain direction is emphasised by the alignment of the lead-rich areas highlighted through chemical mapping (see Fig. 5). Few grains visible close to the coins' surface show strain lines, confirming that they were distorted through coin striking, however this feature is rarely observed in the coin microstructures, which may be explained by the lead contents. The results from Vickers Hardness testing showed no correlation between hardness values and alloy type or coin type.

\section{Nummi minimi}

It should be noted that seven of the coins analysed contained average $\mathrm{Cl}$ contents above $1 \mathrm{wt} \%$ consistent with corrosion and therefore these results should be treated cautiously. Of the 59 nummi minimi selected for chemical analysis, four were identified as being heavily corroded only after sampling and therefore were not analysed (J16-Xb-1-21, J16-Sc-1-2, J16$\mathrm{Xd}-2-28, \mathrm{~J} 15-\mathrm{Pb}-16-2 \mathrm{x}$ ). In addition a fifth coin was confirmed to be heavily corroded during chemical analysis (J16Xf-2-242). The chemical results total 54 analysed nummi minimi $($ Roman $=1$, Late Roman $=49$; Late Roman/Early Byzantine transition $=2$; Byzantine $=2$ ). The archaeological context of the coins indicates they remained in use up to the end of the Umayyad period. It was not possible to assign more refined dating to 24 of the Late Roman nummi minimi, but their compositions might be better understood in relation to those nummi minimi that have been dated more narrowly to a specific ruler or a century. Six nummi minimi have been assigned to the fourth century CE, 24 to the fifth century $\mathrm{CE}$, whilst the five Late Roman/Early Byzantine transition (fifth-sixth centuries CE) and Byzantine coins have been grouped together here under the 'sixth century CE'. Overall, the nummi minimi analysed can be separated into three broad alloys: $13 \%$ are copper, $33 \%$ are leaded bronze and $54 \%$ are leaded copper. More detailed descriptions of the 34 coins that were unambiguously dated are given below.

\section{Fourth century CE}

Six nummi minimi are dated to the fourth century, four to the late fourth century Theodosius I (379-395 CE). With the exception of one coin presumed to be minted under Theodosius I (J16-Xb-2-51), which is a leaded bronze ( $17 \mathrm{wt} \% \mathrm{~Pb}, 3 \mathrm{wt} \%$ $\mathrm{Sn})$, the remainder are made of copper $(\approx 96.1-98.7 \mathrm{wt} \%)$. The coppers contain small amounts of lead (0.7-3.2 wt \%), including minor amounts of As and Fe (J16-Sc-2-4, J16-Ud1-23, J16-Xb-2-51, J16-Xe-2-206).

\section{Fifth century CE}

In the fifth century, there was a noticeable shift away from the use of copper, in favour of copper alloys. Only two of the coins analysed are classified as copper, with the rest (91\%) being copper alloys. In roughly equal parts, 11 coins are classified as leaded bronze and 9 as leaded copper.

Twenty-three nummi minimi could be dated broadly to the fifth century. Some of these could be dated more specifically, three to Theodosius II (401-450 CE), one to Marcian (450$457 \mathrm{CE}$ ), two to Leo (457-474 CE), and two to Zeno (474$491 \mathrm{CE})$. There appears to be a general reduction in copper content from Theodosius II $(\approx 87-97 \mathrm{wt} \% \mathrm{Cu})$, to Marcian 
Table 2 Coin identifications in this study

\begin{tabular}{|c|c|c|c|c|}
\hline Jerash ID & Coin ID & Date & Period & Notes (Schulze and Schulze) \\
\hline $\mathrm{J} 16-\mathrm{Xb}-2-39$ & $\mathrm{C} 24$ & Roman & & Minimus; Roman \\
\hline J16-Sc-1-1 & $\mathrm{C} 5$ & Late Roman & & Minimus; Late Roman \\
\hline J16-Xb-1-21 & $\mathrm{C} 16$ & Late Roman & & Minimus; Late Roman \\
\hline J16-Sc-13-8 & $\mathrm{C} 40$ & Late Roman & & Minimus; Late Roman \\
\hline $\mathrm{J} 16-\mathrm{Xb}-2-53$ & $\mathrm{C} 53$ & Late Roman & & Minimus; Late Roman \\
\hline J16-Xa-2-109 & C61 & Late Roman & & Minimus; Late Roman \\
\hline J16-Sc-13-16 & $\mathrm{C} 63$ & Late Roman & & Minimus; Late Roman \\
\hline J15-Pbd-83-1 & C68 & Late Roman & & Minimus; Late Roman \\
\hline J16-Xa-2-125 & $\mathrm{C} 75$ & Late Roman & & Minimus; Late Roman \\
\hline J16-Sb-1-47 & $\mathrm{C} 78$ & Late Roman & & Minimus; Late Roman \\
\hline J16-Xa-2-130 & $\mathrm{C} 83$ & Late Roman & & Minimus; Late Roman \\
\hline J14-Kf-3-28x & $\mathrm{C} 86$ & Late Roman & & Minimus; Late Roman \\
\hline J14-Ke-3N-18x & $\mathrm{C} 88$ & Late Roman & & Minimus; Late Roman \\
\hline J13-Fc-52-5 & C101 & Late Roman & & Minimus; Late Roman \\
\hline $\mathrm{J} 15-\mathrm{Nb}-57-196$ & C115 & Late Roman & & Minimus; Late Roman; possibly barbarous imitation \\
\hline J16-Sd-29-29 & $\mathrm{C} 122$ & Late Roman & & Minimus; Late Roman \\
\hline J16-Xd-2-180 & C132 & Late Roman & & Minimus; Late Roman \\
\hline $\mathrm{J} 16-\mathrm{Sb}-22-35$ & $\mathrm{C} 151$ & Late Roman & & Minimus; Late Roman \\
\hline $\mathrm{J} 16-\mathrm{Xe}-2-220$ & $\mathrm{C} 165$ & Late Roman & & Minimus; Late Roman \\
\hline J16-Se-22-58 & $\mathrm{C} 176$ & Late Roman & & Minimus; Late Roman \\
\hline J16-Se-21-21 & $\mathrm{C} 177$ & Late Roman & & Minimus; Late Roman \\
\hline J16-Ud-59-2x & $\mathrm{C} 185$ & Late Roman & & Minimus; Late Roman \\
\hline J16-Xf-7-54 & C195 & Late Roman & & Minimus; Late Roman \\
\hline J16-Td-13-1x & C199 & Late Roman & & Minimus; Late Roman \\
\hline J16-Sc-2-4 & $\mathrm{C} 3$ & Late Roman & 4th century & Minimus; Late Roman; Theodosius; minted 388-395 \\
\hline J16-Sc-1-2 & C6 & Late Roman & 4th century & Minimus; Late Roman; presumably minted around 400 \\
\hline J16-Ud-1-23 & $\mathrm{C} 30$ & Late Roman & 4th century & Minimus; Late Roman; Theodosius I. \\
\hline $\mathrm{J} 16-\mathrm{Xb}-2-51$ & C51 & Late Roman & 4th century & Minimus; Late Roman; presumably under Theodosius \\
\hline $\mathrm{J} 16-\mathrm{Xe}-2-206$ & C146 & Late Roman & 4th century & Minimus; Late Roman; Theodosius I; Constantinople mint \\
\hline J16-Ud-52-7 & $\mathrm{C} 245$ & Late Roman & 4th century & Minimus; Late Roman; 4th century \\
\hline J16-Xd-2-18 & $\mathrm{C} 4$ & Late Roman & 5 th century & Minimus; Late Roman; presumably Leo I \\
\hline J16-W-0-9 & $\mathrm{C} 8$ & Late Roman & 5 th century & Minimus; Late Roman; 5th century \\
\hline J16-Xd-2-28 & $\mathrm{C} 15$ & Late Roman & 5th century & Minimus; Late Roman; 5th century \\
\hline J16-Xa-2-83 & $\mathrm{C} 43$ & Late Roman & 5 th century & Minimus; Late Roman under Zeno \\
\hline J16-Xa-2-89 & $\mathrm{C} 49$ & Late Roman & 5 th century & Minimus; Late Roman; presumably under Zeno \\
\hline J16-Sb-21-4 & $\mathrm{C} 81$ & Late Roman & 5 th century & Minimus; Late Roman; 5th century \\
\hline J16-Xa-2-131 & $\mathrm{C} 84$ & Late Roman & 5th century & Minimus; Late Roman; 5th century \\
\hline J16-Sd-29-11 & $\mathrm{C} 92$ & Late Roman & 5th century & Minimus; Late Roman; presumably 5 th century \\
\hline J16-Sd-29-12 & $\mathrm{C} 93$ & Late Roman & 5 th century & Minimus; Late Roman; 5th century \\
\hline $\mathrm{J} 16-\mathrm{Xb}-2-148$ & C96 & Late Roman & 5 th century & Minimus; Late Roman; 5th century \\
\hline $\mathrm{J} 16-\mathrm{Xb}-4-17$ & $\mathrm{C} 105$ & Late Roman & 5 th century & Minimus; Late Roman; presumably Theodosius II \\
\hline J14-Jh-97-13 & C117 & Late Roman & 5 th century & Minimus; Late Roman or early Byzantine \\
\hline $\mathrm{J} 16-\mathrm{Xd}-4-30$ & C119 & Late Roman & 5 th century & Minimus; Late Roman; 5th century \\
\hline J16-Xd-2-199 & $\mathrm{C} 141$ & Late Roman & 5 th century & Minimus; Late Roman; presumably Theodosius II \\
\hline J16-Ta-22-11 & $\mathrm{C} 183$ & Late Roman & 5 th century & Minimus; Late Roman; 5 th century \\
\hline$J 16-X f-2-242$ & $\mathrm{C} 205$ & Late Roman & 5 th century & Minimus; Late Roman; 5th century \\
\hline J16-Ud-56-8 & $\mathrm{C} 225$ & Late Roman & 5 th century & Minimus. Late Roman; 5 th century \\
\hline J16-Sf-22-121 & $\mathrm{C} 237$ & Late Roman & 5 th century & Minimus; Late Roman; 5th century \\
\hline J16-Sf-21-27 & $\mathrm{C} 252$ & Late Roman & 5th century & Minimus of Theodosius II or Leo I \\
\hline J16-Ud-56-21 & $\mathrm{C} 294$ & Late Roman & 5 th century & Minimus; Late Roman; 5th century \\
\hline J16-Uc-68-1 & $\mathrm{C} 295$ & Late Roman & 5 th century & Minimus; Late Roman; 5th century \\
\hline J16-Vdf-25-1x & $\mathrm{C} 311$ & Late Roman & 5 th century & Minimus; Late Roman; presumably Leo I \\
\hline J16-Xc-11-23 & $\mathrm{C} 322$ & Late Roman & 5 th century & Minimus; Late Roman; Marcian \\
\hline J16-Vdf-73-36 & $\mathrm{C} 333$ & Late Roman & 5 th century & Minimus; Late Roman; 5th century; fragment \\
\hline $\mathrm{J} 16-\mathrm{Xb}-7-11$ & $\mathrm{C} 35$ & Roman/Byzantine & 5th-6th century & Minimus; Late Roman or early Byzantine \\
\hline J15-Pd-16-12x & $\mathrm{C} 34$ & Byzantine & 5 th-6th century & Minimus; presumably early Byzantine; bust facing \\
\hline $\mathrm{J} 15-\mathrm{Pb}-16-2 \mathrm{x}$ & $\mathrm{C} 43$ & Byzantine & 6th century & Minimus; presumably Byzantine \\
\hline $\mathrm{J} 15-\mathrm{Nb}-57-197$ & C116 & Byzantine & 6th century & Minimus; presumably Byzantine \\
\hline $\mathrm{J} 15-\mathrm{Nb}-57-200$ & C119 & Byzantine & 6th century & Minimus; presumably Byzantine \\
\hline J16-Vh-26-64 & $\mathrm{C} 88$ & Umayyad & Pre-reform & $\begin{array}{l}\text { Umayyad pre-reform fals; phase } 1 \text { class } 4 \text { (pseudo-Byzantine); } \\
\text { typical cut coin, no fragment }\end{array}$ \\
\hline J16-Uc-45-2x & $\mathrm{C} 232$ & Umayyad & Pre-reform & Umayyad pre-reform fals; phase 1 class 4 (pseudo-Byzantine) \\
\hline J16-Uc-60-13x & $\mathrm{C} 265$ & Umayyad & Pre-reform & $\begin{array}{l}\text { Umayyad pre-reform fals; phase 2; Skythopolis mint; Oddy (2015) } \\
\text { fig. } 12 \text { coin } 10(4.85 \mathrm{~g})\end{array}$ \\
\hline
\end{tabular}


Table 2 (continued)

\begin{tabular}{|c|c|c|c|c|}
\hline Jerash ID & Coin ID & Date & Period & Notes (Schulze and Schulze) \\
\hline J16-Xd-1-5 & $\mathrm{C} 11$ & Umayyad & Post-reform & $\begin{array}{l}\text { Umayyad post-reform fals; Damascus mint; Walker } 816 \\
\text { and Bone } 16 \text { (Umayyad), Ilisch SNAT IVb1 } 266 \text { ff. ('Abbasid) }\end{array}$ \\
\hline J16-Uc-1-30 & $\mathrm{C} 70$ & Umayyad & Post-reform & Umayyad post-reform fals; Shahada only \\
\hline J16-Uc-19-3 & C76 & Umayyad & Post-reform & Umayyad post-reform fals; Jerash mint; SNAT IV a, 277, SICA 2, 1142 f. \\
\hline $\mathrm{J} 14-\mathrm{Kh}-44-2 \mathrm{x}$ & C84 & Umayyad & Post-reform & Umayyad post-reform fals; Tabariya mint; SNAT IV a, 345 ff. \\
\hline J14-Keg-57-1 & C92 & Umayyad & Post-reform & Umayyad post-reform fals; damaged \\
\hline J16-Ud-51-1x & $\mathrm{C} 192$ & Umayyad & Post-reform & $\begin{array}{l}\text { Umayyad post-reform fals; Al-Walid I Fals of } 20 \text { Qīrāt. } \\
\text { Tabariya mint; SNAT IVa, } 313 \text { ff. }\end{array}$ \\
\hline $\mathrm{J} 16-\mathrm{Xf}-1-70$ & $\mathrm{C} 210$ & Umayyad & Post-reform & Umayyad post-reform fals; Shahada only \\
\hline J16-Ud-11-12 & $\mathrm{C} 240$ & Umayyad & Post-reform & Umayyad post-reform fals; Shahada only \\
\hline J16-Uc-60-6x & $\mathrm{C} 293$ & Umayyad & Post-reform & Umayyad post-reform fals; Shahada only \\
\hline
\end{tabular}

$(\approx 89 \mathrm{wt} \% \mathrm{Cu})$ to Leo $(77-78 \mathrm{wt} \% \mathrm{Cu})$, but this does not continue through to Zeno $(\approx 81-85 \mathrm{wt} \% \mathrm{Cu})$.

\section{Sixth century CE (Late Roman/Byzantine)}

The coins grouped together here for this period include the Byzantine coins as well as those that are more loosely dated to the Late Roman/Early Byzantine transition. They are all leaded copper. No zinc is observed and the tin concentrations are very low in comparison with the earlier nummi minimi, reaching a maximum of $0.8 \mathrm{wt} \% \mathrm{Sn}$.

\section{Umayyad fulūs}

\section{Pre-reform}

Of the three pre-reform fulūs analysed, the two identified from Phase 1 (categorised as Pseudo-Byzantine) are very similar in their composition (J16-Vh-26-64, J16-Uc-45$2 \mathrm{x})$. They are $\approx 98 \mathrm{wt} \% \mathrm{Cu}$ with $\approx 1.4-1.6 \mathrm{wt} \% \mathrm{~Pb}$. The minor/trace impurities observed (below detection limits) can occur in pure copper smelted from relatively pure ores (cf. Hauptmann et al. 1992, pp. 22-24; Hauptmann 2007,

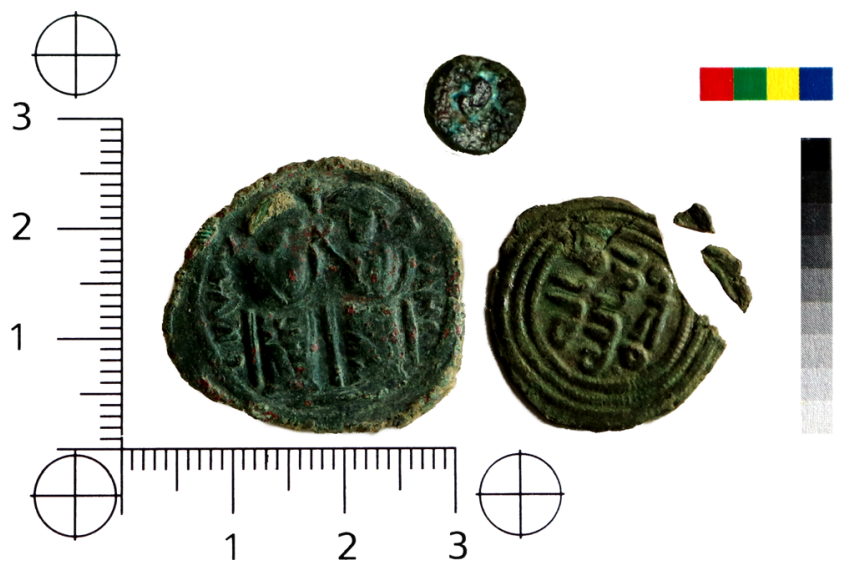

Fig. 2 Examples of a minimus (top), a pre-reform Umayyad fals of Skythopolis imitating a Byzantine follis of Justin II and a purely epigraphic post-reform Umayyad fals of Jerash. Scale in $\mathrm{cm}$ pp. 200-205). The third pre-reform fals, from Phase 2, is distinctly different in its composition, with $0.2 \mathrm{wt} \%$ As, $1.4 \mathrm{wt} \% \mathrm{Sn}$ and $0.4 \mathrm{wt} \% \mathrm{Zn}$ (J16-Uc-60-13x).

\section{Post-reform fulūs}

With the exception of one post-reform fals (J16-Uc-60-6x), the remaining post-reform fulüs are all copper alloys. The metal of choice appears to have been leaded bronze ranging from $\approx 2$ $4 \mathrm{wt} \% \mathrm{Sn}$ and $\approx 12-17 \mathrm{wt} \% \mathrm{~Pb}$ (J14-Kh-44-2x, J14-Keg-57-1, J16-Xd-1-5, J16-Uc-19-3, J16-Ud-51-1x, J16-Xf-1-70, J16Ud-11-12), though one contains $7 \mathrm{wt} \% \mathrm{~Pb}$ (J16-Uc-60-6x). One of the copper alloy fals is a leaded brass with $\approx 4 \mathrm{wt} \%$ $\mathrm{Zn}$, though also containing $1.8 \mathrm{wt} \% \mathrm{Sn}$ (J16-Uc-1-30).

\section{nummi minimi weights}

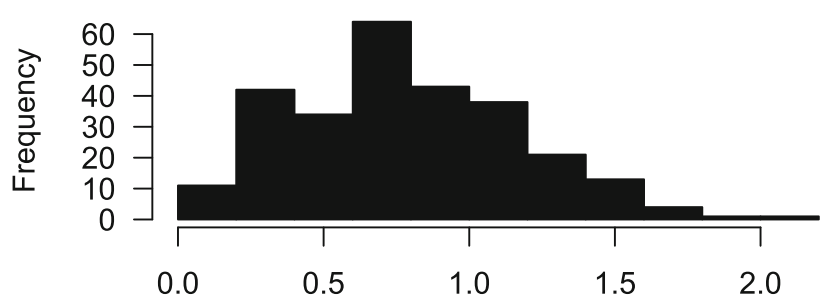

Weight (g)

nummi minimi size

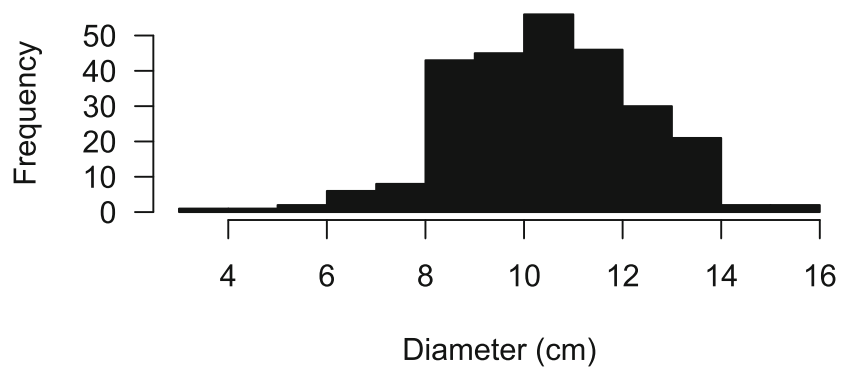

Fig. 3 Histograms of the weight and diameter of nummi minimi recovered from the Danish-German Jerash Northwest Quarter Project 


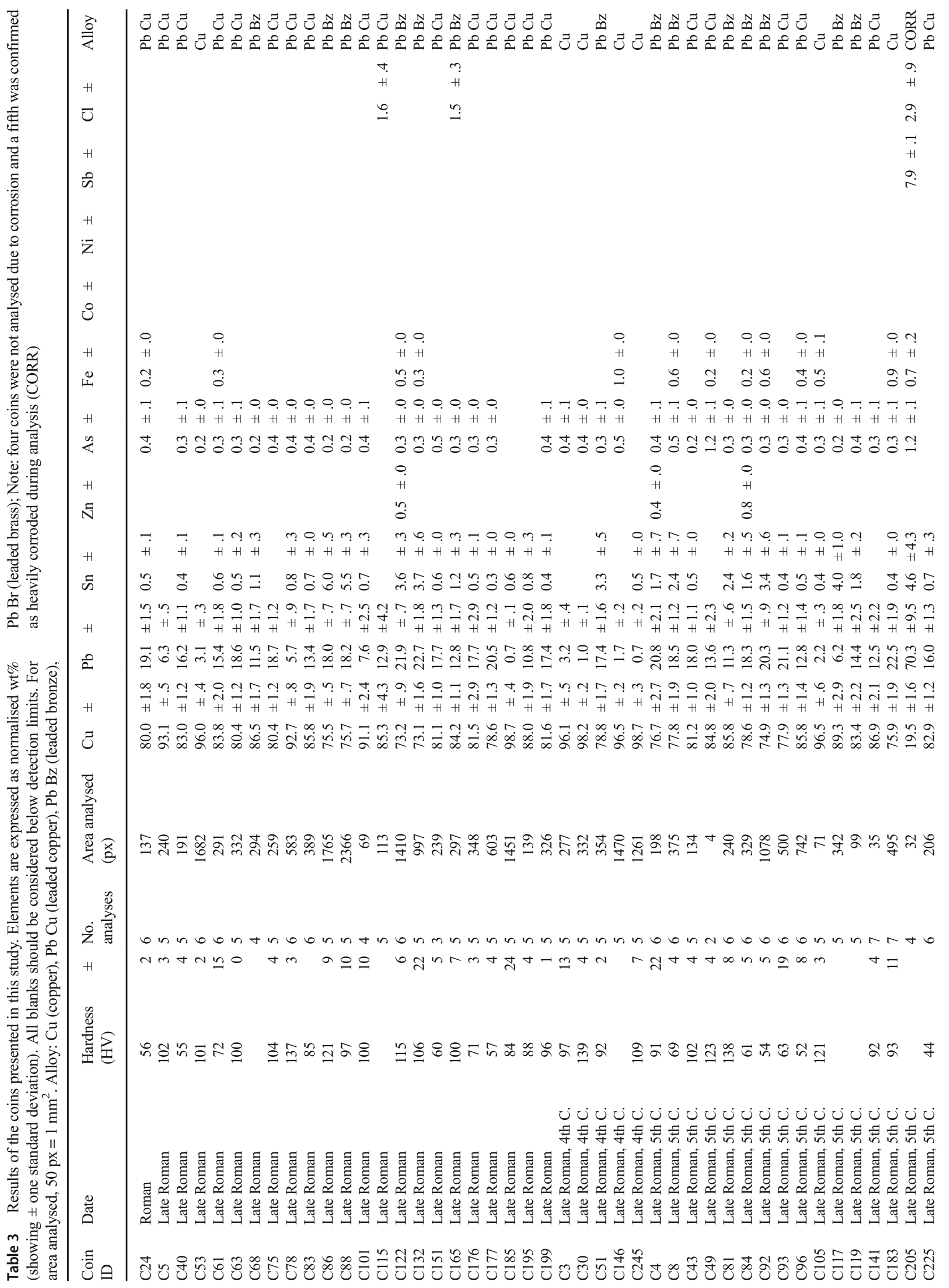




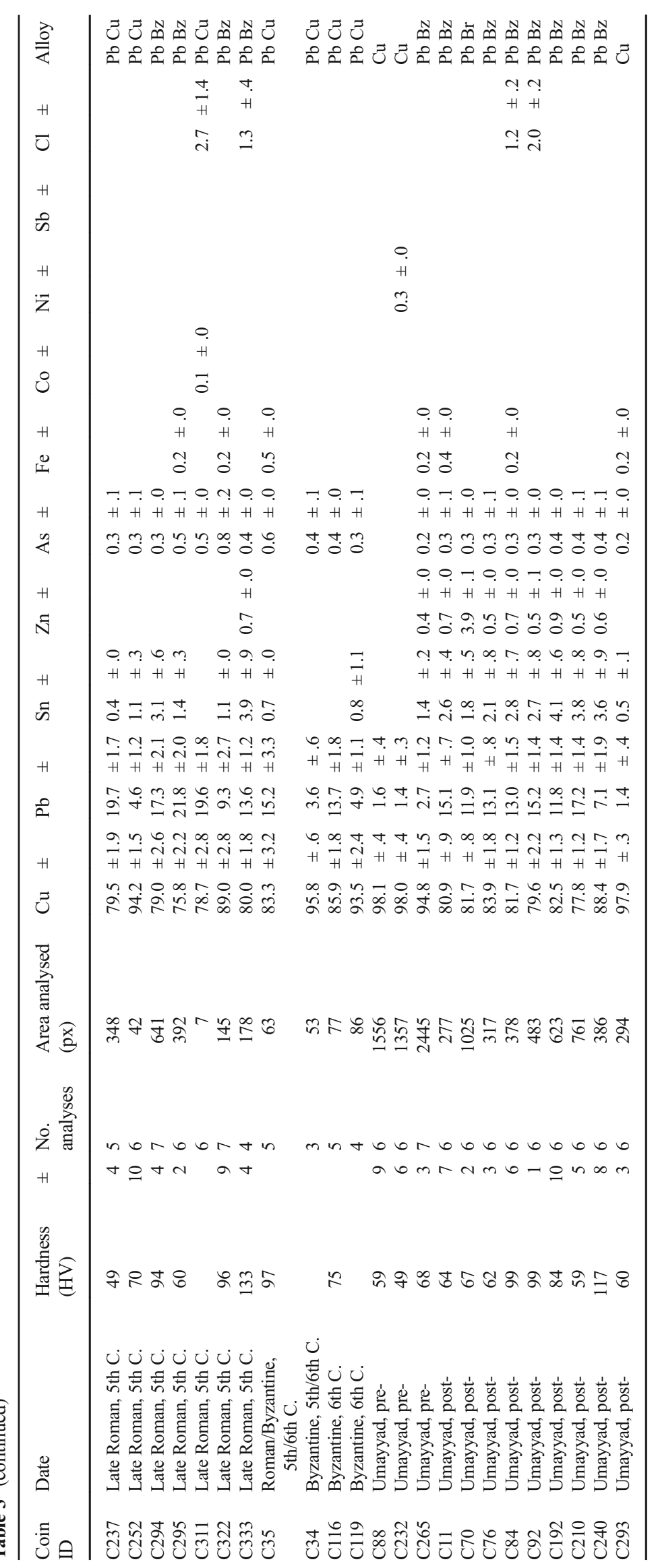




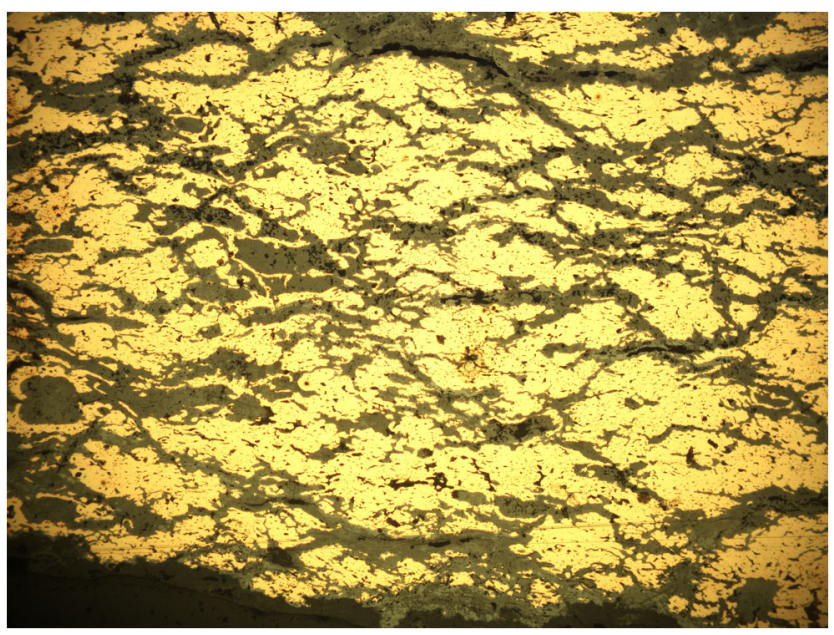

Fig. 4 Photomicrograph of an unetched Byzantine impure copper coin's polished cross-section showing a dendritic structure, visible throughout the cross-section, suggestive of casting. Intra-granular corrosion (grey) can be observed along grain boundaries with an overall directional preference aligned with coin striking. Image width $=160 \mu \mathrm{m}$

\section{Lead isotope analysis}

Sixteen coins were selected for $\mathrm{Pb}$ isotope analysis. These include five Late Roman copper nummi minimi, eight Late Roman leaded copper alloy nummi minimi, and three Umayyad copper fulūs. The $\mathrm{Pb}$ isotope values of the coins show a large range, with ${ }^{206} \mathrm{~Pb} /{ }^{204} \mathrm{~Pb}$ ratios from 18.262 to $18.824,{ }^{207} \mathrm{~Pb} /{ }^{204} \mathrm{~Pb}$ ratios from 15.656 to 15.688 , ${ }^{208} \mathrm{~Pb} /{ }^{204} \mathrm{~Pb}$ ratios from 38.423 to 38.905 . The $\mathrm{Pb}$ isotope results are reported in Table 4, with the full results (replicates, blank and standards) provided as supplementary material (S3).

\section{Discussion}

The following focuses on the observations made from coin compositions and microstructures of nummi minimi and fulūs. The possible metal origins of copper and lead are also

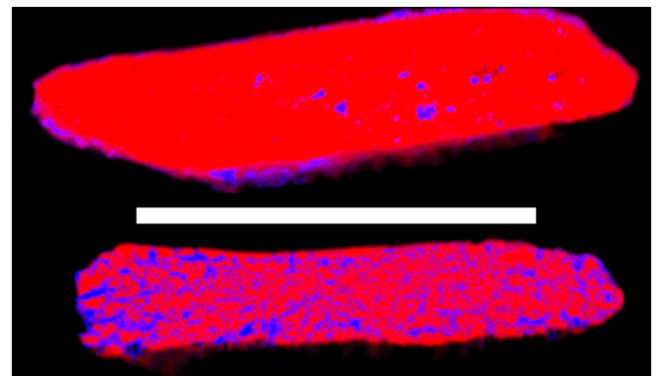

Fig. 5 Chemical mapping of a heavily leaded minimus (bottom) and an unleaded copper alloy minimus (top); blue represents the distribution of lead $(\mathrm{Pb})$, corresponding with observed intergranular corrosion, and red represents the distribution of copper $(\mathrm{Cu})$. Scale bar $=5 \mathrm{~mm}$ investigated before synthesising a more general discussion on the fifth century CE 'monetary crisis' and 'Abd al-Malik's monetary reform. The range and mean values of copper and the main alloying elements of interest of the copper-based coinage studied here for each century (nummi minimi) and period (Umayyad pre- and post-reform) are shown in Table 5 and illustrated in Fig. 6. This paper does not seek to identify differences between mints, which is invariably impossible for many of the nummi minimi.

\section{Nummi minimi}

With the exception of the single leaded bronze coin, the remaining coins analysed from the fourth century $\mathrm{CE}$ are made from a relatively pure smelted copper (or re-melted product thereof) with a relative absence of $\mathrm{Sn}$ and $\mathrm{Zn}$, and thus not the product of recycling copper alloys.

When all the dated nummi minimi are taken into account, the increased debasement in the fifth century CE is more visible (see Fig. 7). The debasement of nummi minimi with lead in the fifth century CE has also been observed in the Western Roman Empire (Canovaro et al. 2013, 2015; Scuotto et al. 2014); however, with this study the same phenomenon can be tracked in the East, where very few scientific investigations have taken place (King et al. 1992; al-Sa'ad et al. 2000).

A clear drop in the copper content is visible in the fifth century CE nummi minimi, to around $83 \mathrm{wt} \% \mathrm{Cu}$. This coincides with a notable increase in lead, the main alloying component $(\approx 15 \mathrm{wt} \%$ ), as well as tin and zinc. Not only is the copper used clearly being heavily debased with lead, but the base metal being used derives from recycled copper alloys, such as bronze or even brass (see J16-Xa-2-131 and J16-Vdf$25-1 \mathrm{x})$. The results here are in good agreement with those coins published from the East, showing higher lead contents than the West (King et al. 1992, p. 62).

When the different alloy types are grouped roughly by period (where possible), some interesting observations emerge (see Fig. 8). Despite the small number of coins analysed, the fourth century is characterised by the use of copper, with the exception of one coin. The fifth century, however, is characterised by a diversity of alloys, with all four being present, notably with a high proportion of leaded bronze and leaded copper. The shift from the fourth century to the fifth century, therefore, is marked by the use of copper alloys (probably recycled bronze) along with copper, which have been debased with lead. It is difficult to claim, based on four coins, that the Byzantine nummi minimi represent a preference for leaded copper, but the results do indicate a change from the diversity of copper alloys observed in the fifth century. When the minimi compositions are compared directly to available published data, as shown in Fig. 9, from the Western Roman Empire (cf: Canovaro et al. 2013), it is clear that the fifth century minimi from Gerasa/Jerash display a much wider 


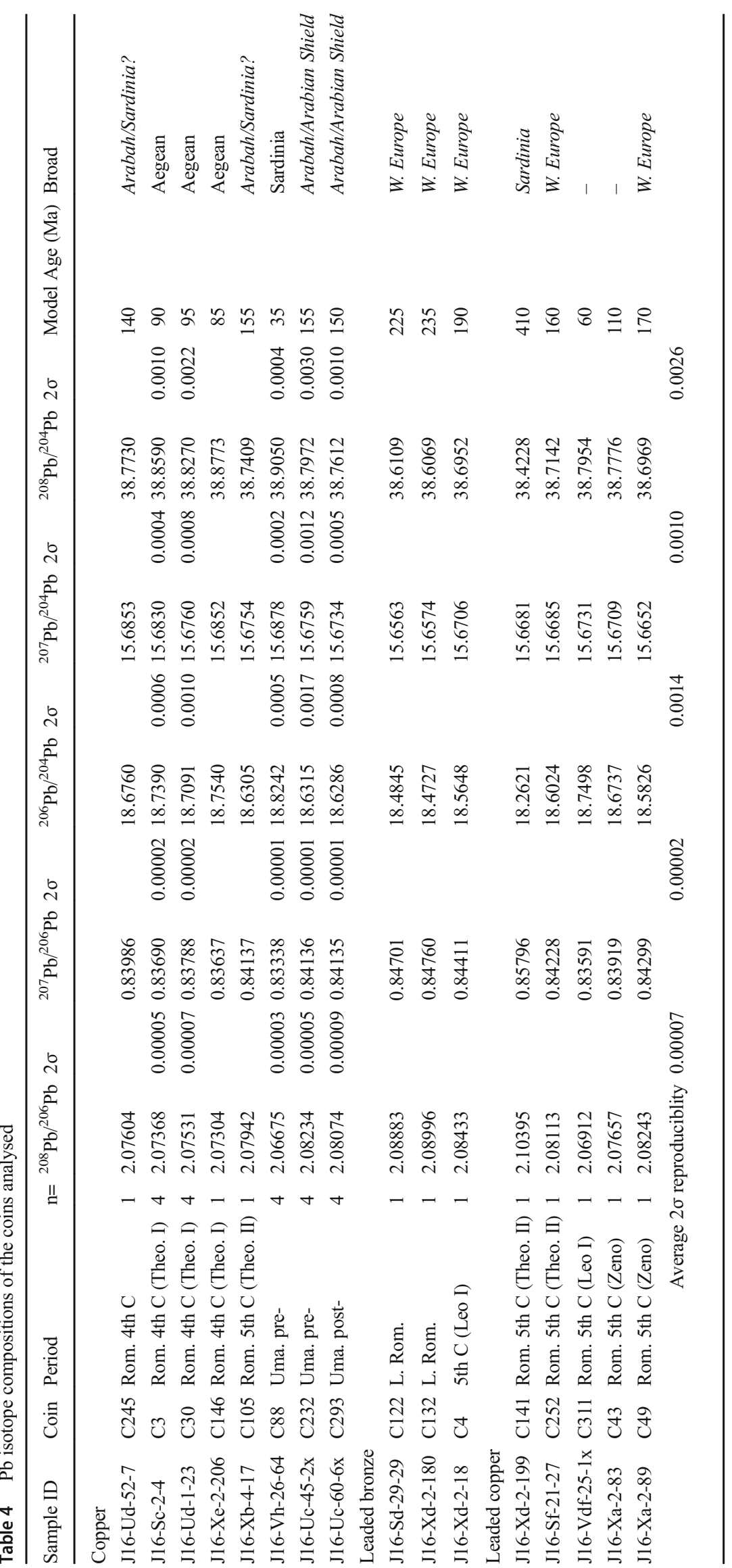


Table 5 Range and mean values for copper, lead, tin and zinc for each century (bd = beneath detection limits); HV = Vickers hardness

\begin{tabular}{|c|c|c|c|c|c|c|c|c|c|c|c|c|c|}
\hline \multirow[b]{2}{*}{ Period } & \multicolumn{3}{|c|}{$\mathrm{Cu}$ wt $\%$} & \multicolumn{3}{|c|}{$\mathrm{Pb}$ wt $\%$} & \multicolumn{3}{|c|}{ Sn wt $\%$} & \multicolumn{3}{|c|}{$\mathrm{Zn} \mathrm{wt} \%$} & \multirow{2}{*}{$\begin{array}{l}\mathrm{HV} \\
\text { Mean }\end{array}$} \\
\hline & Min & Mean & Max & Min & Mean & Max & Min & Mean & Max & Min & Mean & Max & \\
\hline 4th CE & 78.8 & 93.7 & 98.7 & 0.7 & 4.8 & 17.4 & 0.5 & 1.9 & 3.3 & bd & - & - & $109 \pm 21$ \\
\hline 5th CE & 78.1 & 82.5 & 96.5 & 2.2 & 15.2 & 22.5 & 0.4 & 1.6 & 4.0 & 0.4 & 0.6 & 0.8 & $84 \pm 29$ \\
\hline (5-) 6th CE & 83.3 & 89.6 & 94.1 & 3.6 & 9.4 & 15.2 & 0.7 & 0.75 & 0.8 & bd & - & - & $86 \pm 16$ \\
\hline Pre- & 94.8 & 97.0 & 98.1 & 1.4 & 1.9 & 2.7 & bd & 1.4 & - & bd & 0.4 & - & $59 \pm 10$ \\
\hline Post- & 77.8 & 83.8 & 97.9 & 1.4 & 11.8 & 17.2 & 0.5 & 2.7 & 4.1 & 0.5 & 1.0 & 3.9 & $79 \pm 21$ \\
\hline
\end{tabular}

distribution in lead contents, reflecting local or regional differences.

In the sixth century $\mathrm{CE}$, the analysed coins are consistently leaded copper, contrasting with the diversity of copper alloys exhibited in the fifth century CE nummi minimi, suggestive of a recovery in the copper content that continued into the Umayyad pre-reform coinage.

\section{Umayyad fulūs}

The transition from the Late Roman/Byzantine nummi minimi to the pre-reform Umayyad fulüs also shows a decrease in alloying components, reflecting an overall transition back towards 'pure' copper base metal for coinage. However, this is short lived, as the post-reform fulüs were made from base metal debased with lead, accompanied by an increase in alloying components, namely $\mathrm{Sn}$ and $\mathrm{Zn}$. Some caution is needed when interpreting these results due to the complex nature of Umayyad coinage. There were different political and economic needs during the different phases of prereform coinage, with old Byzantine coins being re-used primarily in Phase 1 and occasionally in Phases 2 and 3. Similarly, some post-reform coins were overstruck on prereform coins (Qedar 1985).

The main and noteworthy observation of the Phase 1 pre-reform fuluss is that they appear to have been minted with a rather pure copper, compared to the post-reform coinage. They are unsurprisingly soft $(\approx 50-70 \mathrm{HV})$ and have not been hardened through striking after being cast. The minor element composition (for example $\mathrm{Fe}, \mathrm{Zn}, \mathrm{Pb}$, $\mathrm{Ni}$ and As) of this copper can be compared to objects analysed from Faynan (cf: Hauptmann 2007, pp. 200205, 369-371). The copper from Faynan is also regarded as one of the 'lead-richest metals in the Eastern Mediterranean', with a median $\mathrm{Pb}$ value of $1.15 \mathrm{wt} \%$ (Hauptmann 2007, p. 201), close to the value obtained from the two pre-reform fulūs. The single Phase 2 prereform fals analysed (J16-Uc-60-13x) has a tin content incompatible with copper produced from the Arabah and therefore unlikely to be from the region. Still, the copper content is very high (95 wt\%) and consistent with the selection of copper metal for minting pre-reform fulūs. It is not possible to establish if the $2.7 \mathrm{wt} \% \mathrm{~Pb}$ and $1.4 \mathrm{wt} \%$ Sn contents are indicative of recycling a leaded bronze or inherent in the original smelted copper.

What is interesting about the metal composition of the post-reform fulüs is the consistency between mints. The post-reform fulūs identified as being minted in Tabariya, Damascus and Gerasa/Jerash all share a composition of $\approx 81-84 \mathrm{wt} \% \mathrm{Cu}, \approx 2-3 \mathrm{wt} \% \mathrm{Sn}$ and $\approx 13-15 \mathrm{wt} \% \mathrm{~Pb}$. This indicates that minting was regionally organized and controlled so that the same copper alloy supply (or alloying recipe) was utilized across the region, denoting a centralisation of the metal or alloying knowledge supplied to the different mints. These three coins derive from two separate administrations, Jund al-Urdunn (Tabariya and Gerasa/Jerash) and Jund Dimashq (Damascus) (Goodwin and Gyselen 2015, p. 46).

When compared to the results of other Umayyad copperbased coins, our results fit well with those published on Jund al-Urdunn (Goussous 1995; al-Sa'ad and Goussous 1997), showing coins of pure copper and leaded bronze. The mints of Jund Qinnasrin also used bronze with added lead (2.6-5.4 wt\% $\mathrm{Pb})$, as was also the case for Jund Hims (13.1-28.8 wt $\% \mathrm{~Pb}$ ) and even Jund Dimashiq (Goussous 1995, p. 198).

The post-reform fals made of leaded brass is indicative of some recycling of copper alloys (brass and bronze), though the final outcome of the alloy still results in $82 \mathrm{wt} \% \mathrm{Cu}$ and $12 \mathrm{wt} \% \mathrm{~Pb}$ (J16-Uc-1-30). This single example fits well with the copper alloy used to mint coinage in Jund Filastin, which appears to be the only administration to use an $\mathrm{Cu}-\mathrm{Zn}-\mathrm{Sn}$ alloy containing 7.8-11.1 wt\% Zn and 1.7-2.4 wt\% Sn (Goussous 1995, p. 198).

The chronological overview, therefore, reveals fluctuations in both the purity and compositional character of copper coinage from the fourth to the eighth centuries $\mathrm{CE}$. The fluctuations indicate the use of recycled copper alloys as the base metal for nummi minimi in the fifth century $\mathrm{CE}$ and for postreform Umayyad fulūs. This is different from the preference for purer copper in the fourth century CE and pre-reform Umayyad fulūs. It seems, therefore, that two pronounced events of copper debasement took place. 

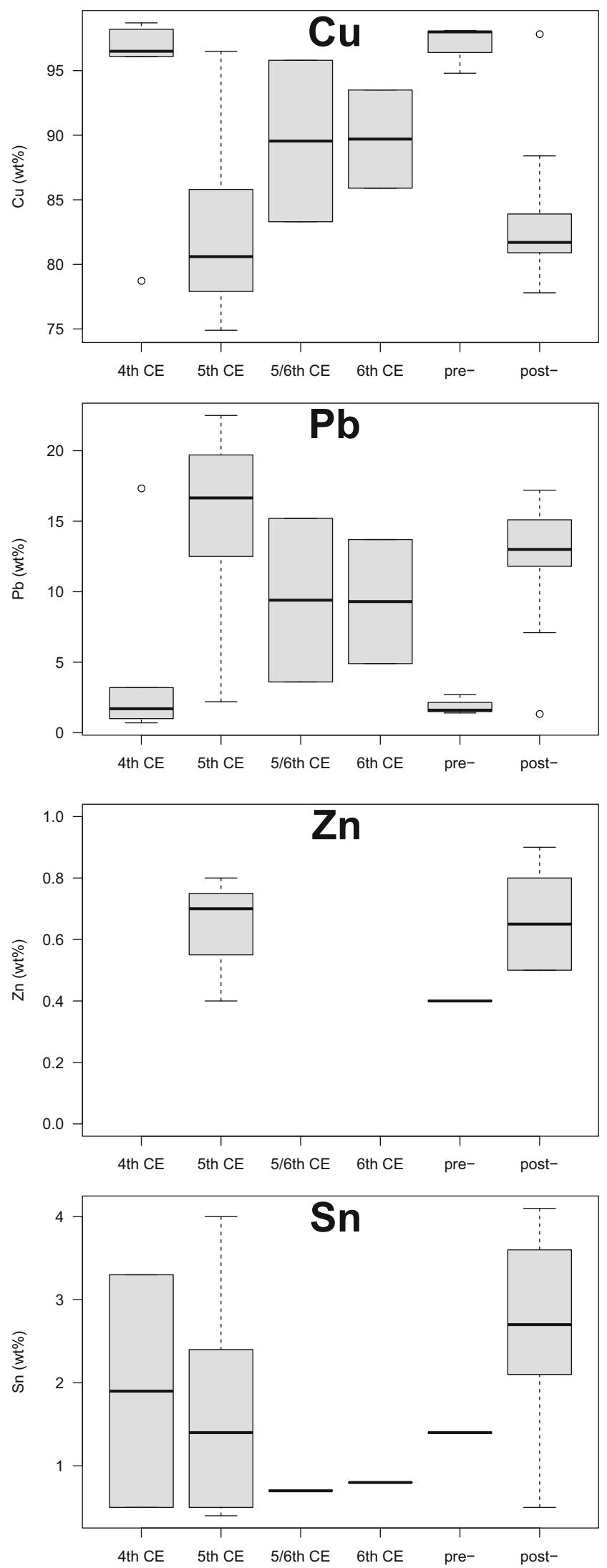

Fig. 6 Boxplot of $\mathrm{Cu}, \mathrm{Pb}, \mathrm{Zn}$ and $\mathrm{Sn}$ concentrations for each period (4th century $\mathrm{CE}=5,5$ th century $=22,5 / 6$ th century $=2$, 6th century $=2$, prereform Umayyad $=3$, post-reform Umayyad $=9$ ). Note: for Zn, two outliers for the 5th century CE (8.5 and $11.2 \mathrm{wt} \%)$ and one outlier of Umayyad post-reform (4.1 wt\%) are beyond the axis limits of the boxplot

\section{Minting technology}

The casting of flans (before being hammered) for both the Roman/Byzantine nummi minimi and Umayyad fulūs, has been observed elsewhere (Canovaro et al. 2013, 2015). However, it is difficult to generalise entirely, as many Umayyad pre-reform coins of Phase 1 (Pseudo-Byzantine) were often overstruck on old Byzantine large folles (which were struck and cut in pieces). No distinction can be made between the 'blank' nummi minimi and others, indicating that the minting technology was similar.

Some 'blank' nummi minimi are referred to as 'unstruck blanks' (Hoover 2005), which appears to denote the lack of any coin devices. However, the microstructures studied here show that these 'blank' nummi minimi were cast and struck, so they were indeed 'struck' blank, rendering the term 'unstruck blanks' somewhat misleading. Similarly, referring to such nummi minimi as 'blank flans' is also misleading, as this would imply that they were simply cast to shape (flans), which is evidently not the case. Our observations and others (Canovaro et al. 2013, 2015) clearly demonstrate that the unmarked nummi minimi are 'minted blanks' - that is to say, they were cast and then struck, indicating that they do bear the hallmarks of a basic minting operation.

The coin microstructures of the Umayyad fulūs is important, as it appears that little is known about how they were minted, since it has even been suggested that they were not cast, at least for Umayyad copper coinage from Spain (Miles 1950, p. 63). Here, we can show otherwise that, like the nummi minimi and other copper alloy coinage before them, they were struck cast flans.

\section{Lead isotope results}

$\mathrm{Pb}$ isotope analysis was performed to investigate the origins of the metals used for producing nummi minimi and fulūs, with a view to comparing the results with locally available copper sources (i.e., Feynan and Timna), as well as other regional sources of lead and copper. $\mathrm{Pb}-\mathrm{Pb}$ model ages of coins were calculated using Stacey and Kramers' (1975) model. $\mathrm{Pb}-\mathrm{Pb}$ model ages were compared to relevant geological sources with similar ages. The Euclidean distances between coins and ore reference data were calculated and the nearest Euclidean neighbours were used to investigate potential provenance of copper and lead metals, which were evaluated in relation to archaeologically relevant ore deposits (Stos-Gale and Gale 2009). The likelihood of mixing makes it difficult to 


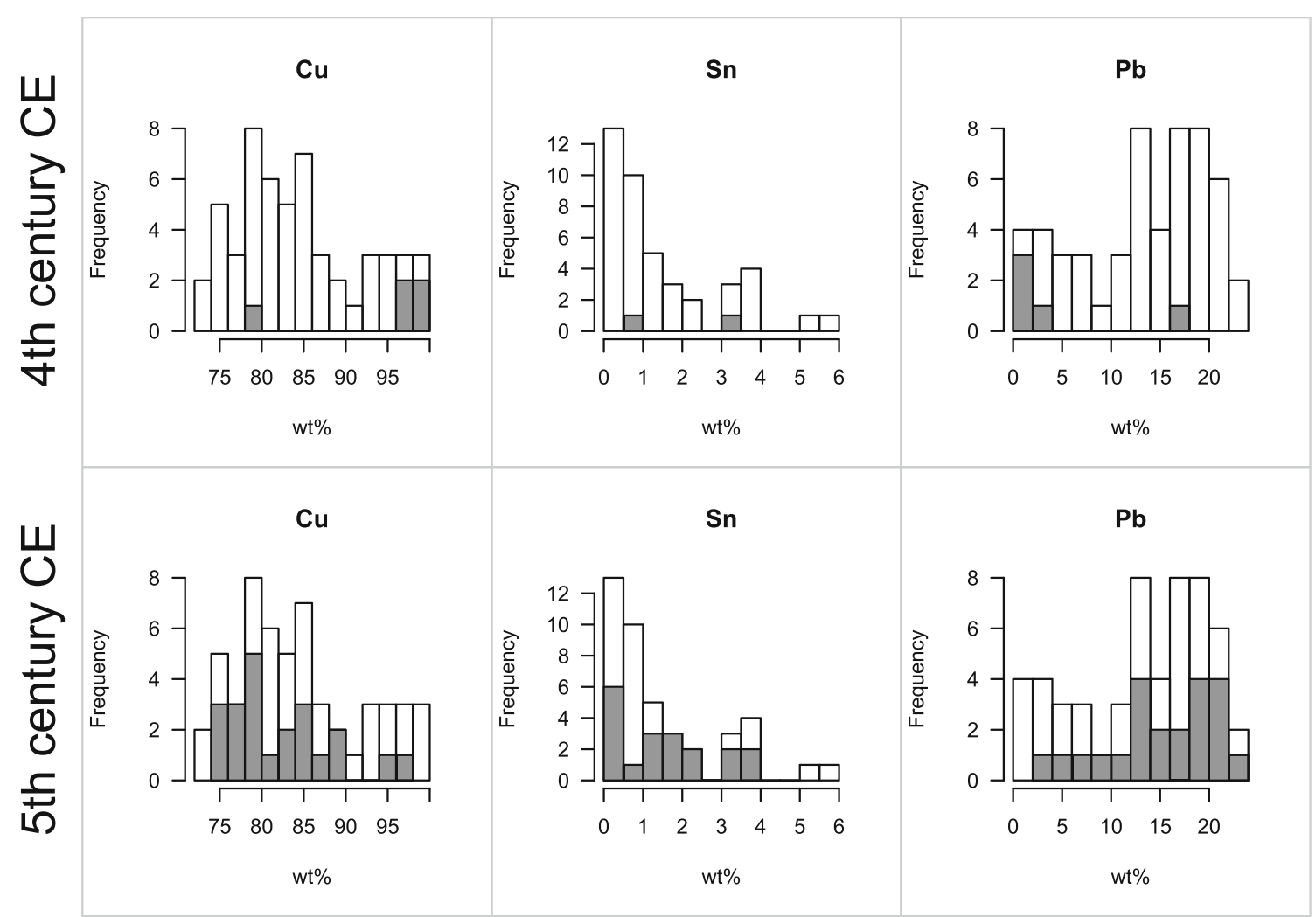

Fig. 7 Histograms comparing the element concentrations (in wt $\%$ ) of $\mathrm{Cu}, \mathrm{Pb}$ and $\mathrm{Sn}$ analysed from the 4th and 5th centuries $\mathrm{CE}$ (highlighted in grey) in relation to the element concentrations of all nummi minimi analysed (white)

directly identify potential metal sources without a more comprehensive analytical programme to try to isolate the main end members.

\section{Copper}

$\mathrm{Pb}$ isotopes for the nine copper coins analysed are shown in Fig. 10. The three copper nummi minimi of Theodosius I (J16$\mathrm{Sc}-2-4, \mathrm{~J} 16-\mathrm{Ud}-1-23, \mathrm{~J} 16-\mathrm{Xe}-2-206)$ have $\mathrm{Pb}-\mathrm{Pb}$ model ages of $\approx 80-100 \mathrm{Ma}$ (Alpine period) and the $\mathrm{Pb}$ isotope ratios are consistent with copper ore sources from the Aegean, namely the Eastern Rhodopes or Western Anatolia (Stos-Gale et al. 1998; Stos-Gale and Gale 2009).

Two other nummi minimi, one dated to Theodosius II (J16$\mathrm{Xb}-4-17)$ and the other more broadly to the fourth century (J16-
Ud-52-7) correspond well with the copper ores from Faynan in Jordan (Hauptmann 2007). Copper ores from Serbia (Pernicka et al. 1993) cannot be ruled out as a potential source; however, their Alpine age ( $\leq 100 \mathrm{Ma})$ is inconsistent with the $\mathrm{Pb}-\mathrm{Pb}$ model ages of the two nummi minimi, which are $\approx 140-155 \mathrm{Ma}$. Copper ores from Sardinia (Stos-Gale and Gale 1992) also correspond well with the Theodosius II coin, which may be a better match than Faynan because of the apparent use of Sardinian copper for nummi minimi of Theodosius I.

The two Umayyad fulüs, one pre-reform (J16-Uc-45-2x) and one post-reform (J16-Uc-60-6x) have very similar $\mathrm{Pb}-\mathrm{Pb}$ model ages of $\approx 150 \mathrm{Ma}$. Their similar $\mathrm{Pb}$ isotope ratios are consistent with copper ores from the Arabah or Arabian Shield, namely Faynan in Jordan or the Samad region in Oman (Hauptmann 2007; Begemann et al. 2010). However, copper ores from
Fig. 8 Barplot showing the relative proportion of different copper (alloys) for each period of interest
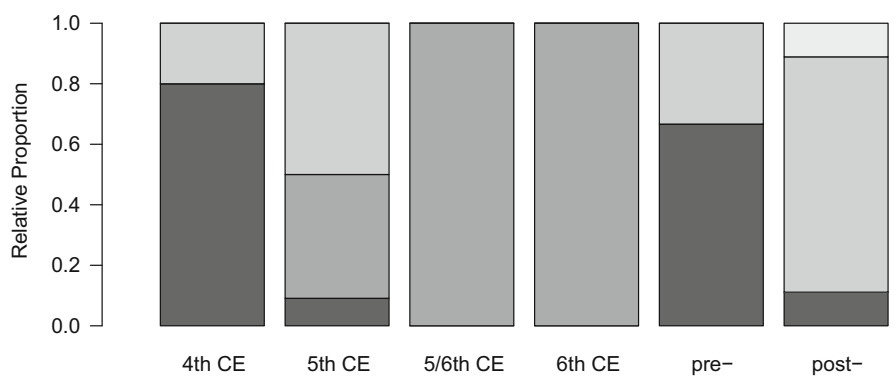

$\square$ leaded brass

$\square$ leaded bronze

$\square$ leaded copper

$\square$ copper 6th CE

Period 


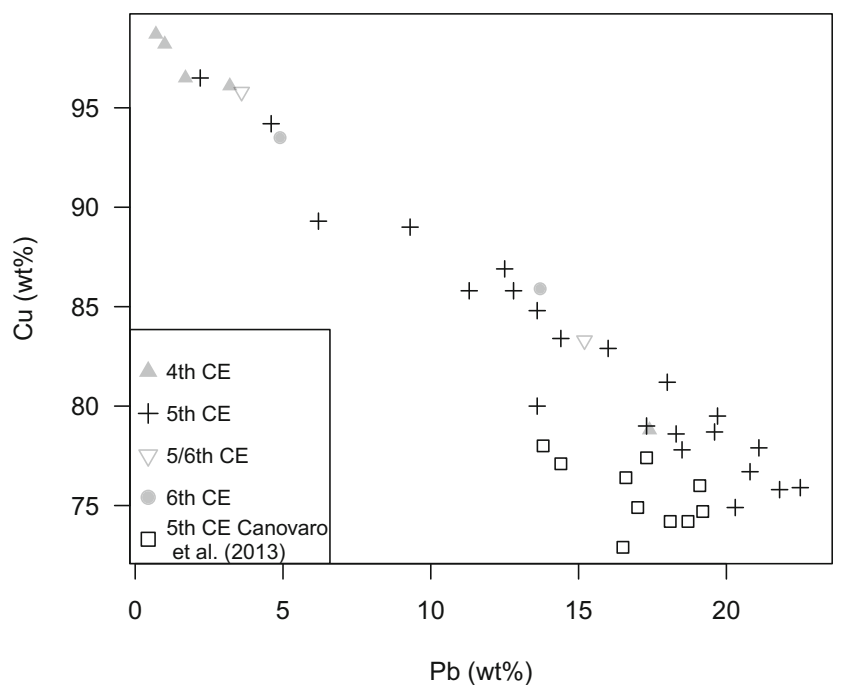

Fig. 9 Biplot of lead and copper concentrations of nummi minimi from Gerasa/Jerash compared to data available from Canovaro et al. (2013)

Sardinia cannot be excluded for the post-reform fals, which may not be surprising if older copper coinage (i.e. Theodosius I and II) was being re-used.

The closest $\mathrm{Pb}$ isotope reference data for the Umayyad prereform fals (J16-Vh-26-64) appears to be copper ores from Sardinia (Stos-Gale et al. 1997).

\section{Leaded copper}

$\mathrm{Pb}$ isotopes for the five leaded copper coins analysed are shown in Fig. 11. The five fifth century leaded copper nummi minimi have $\mathrm{Pb}-\mathrm{Pb}$ model ages ranging from $\approx 60$ to $410 \mathrm{Ma}$. The two Theodosius II nummi minimi have different $\mathrm{Pb}$ isotope compositions, with $\mathrm{Pb}-\mathrm{Pb}$ model ages of $\approx 400 \mathrm{Ma}$ (J16-Xd-2-199) and $160 \mathrm{Ma}$ (J16-Sf-21-27). The two Zeno nummi minimi also have different $\mathrm{Pb}$ isotope compositions and $\mathrm{Pb}-\mathrm{Pb}$ model ages. This indicates that the lead added to debase copper for minting nummi minimi, under both Theodosius II (401-450 CE) and Zeno (474 $491 \mathrm{CE})$, came from different sources. If the two Theodosius II nummi minimi were minted at the same time, the same for the two Zeno coins, then it implies that lead metal of different origins was being mixed with the copper. Despite this, some of the $\mathrm{Pb}$ isotope ratios appear consistent with major Roman lead mining areas (cf: Domergue 2008).

One of the two Theodosius II nummi minimi (J16-Xd-2199 ) is consistent with $\mathrm{Pb}$ isotope signatures from Sardinia (Boni and Koeppel 1985; Ludwig et al. 1989; Valera et al. 2005; Stos-Gale and Gale 2009). The other Theodosius II coin (J16-Sf-21-27), as well as one of Zeno (J16-Xa-2-89) have similar $\mathrm{Pb}-\mathrm{Pb}$ model ages of $\approx 160-170 \mathrm{Ma}$ and $\mathrm{Pb}$ isotope signatures consistent with the Massif Central in France, or Cantabrian Mountains in the Basque Country (Velasco et al. 1996; Baron et al. 2006).
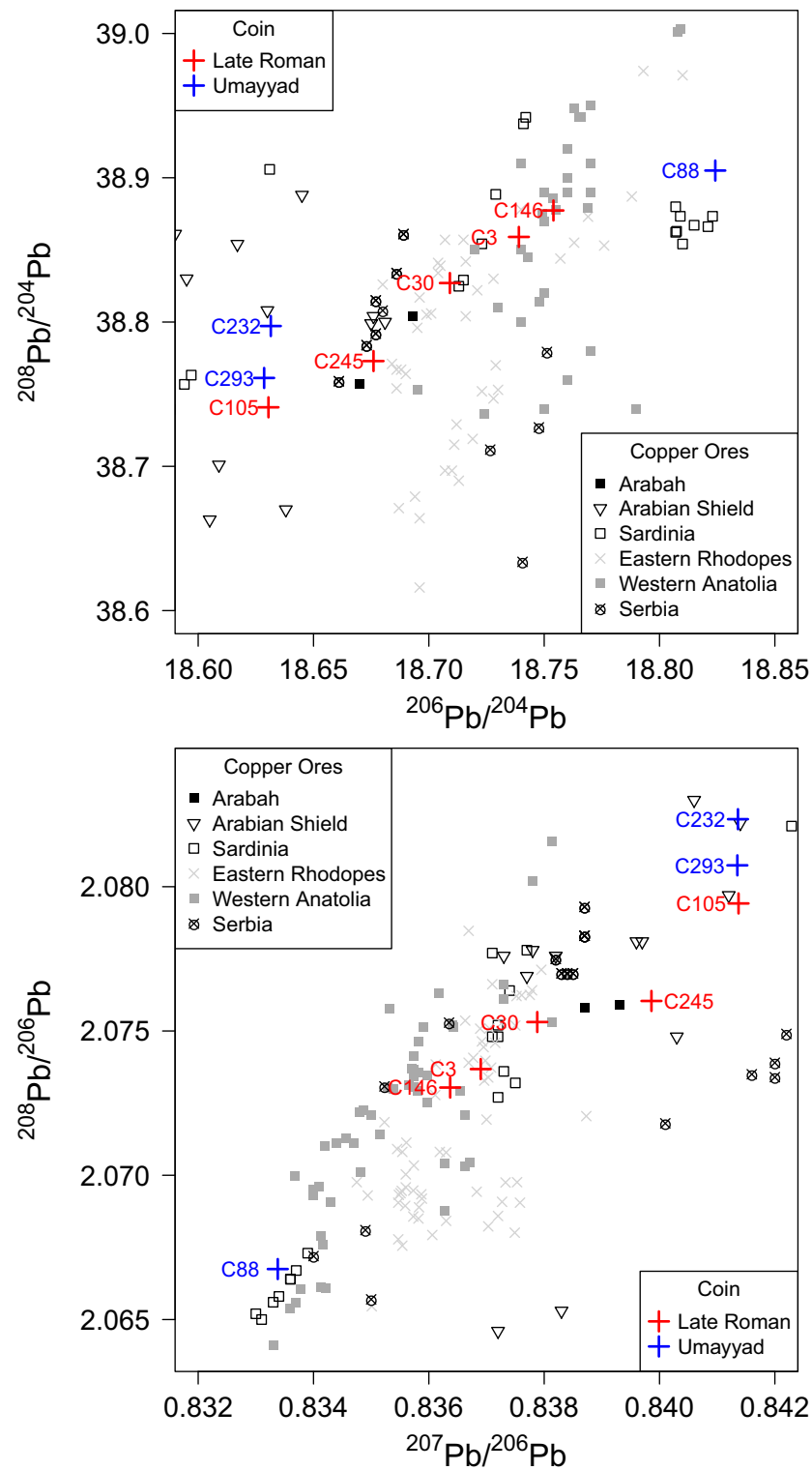

Fig. $10 \mathrm{~Pb}$ isotope diagrams of the copper coins investigated in comparison with literature data of $\mathrm{Cu}$ ores (Stos-Gale and Gale 2009), notably from the Arabah (Hauptmann 2007), Arabian Shield (Begemann et al. 2010), Sardinia (Stos-Gale et al. 1997), Eastern Rhodopes (StosGale et al. 1998), Western Anatolia (Wagner et al. 1985), and Serbia (Pernicka et al. 1993)

This implies that lead originating from Roman mines in France of Spain may have been available for debasing copper in both the first half(Theodosius II) and last quarter (Zeno) of the fifth century, most likely reflecting the re-use of older Roman lead.

\section{Leaded bronze}

$\mathrm{Pb}$ isotopes for the eight leaded copper alloy coins analysed are shown in Fig. 11. Two broadly dated Late Roman nummi minimi (J16-Sd-29-29, J16-Xd-2-180) have a composition very close to the leaded bronze coin (J16-Xd-2-18) of Leo I 

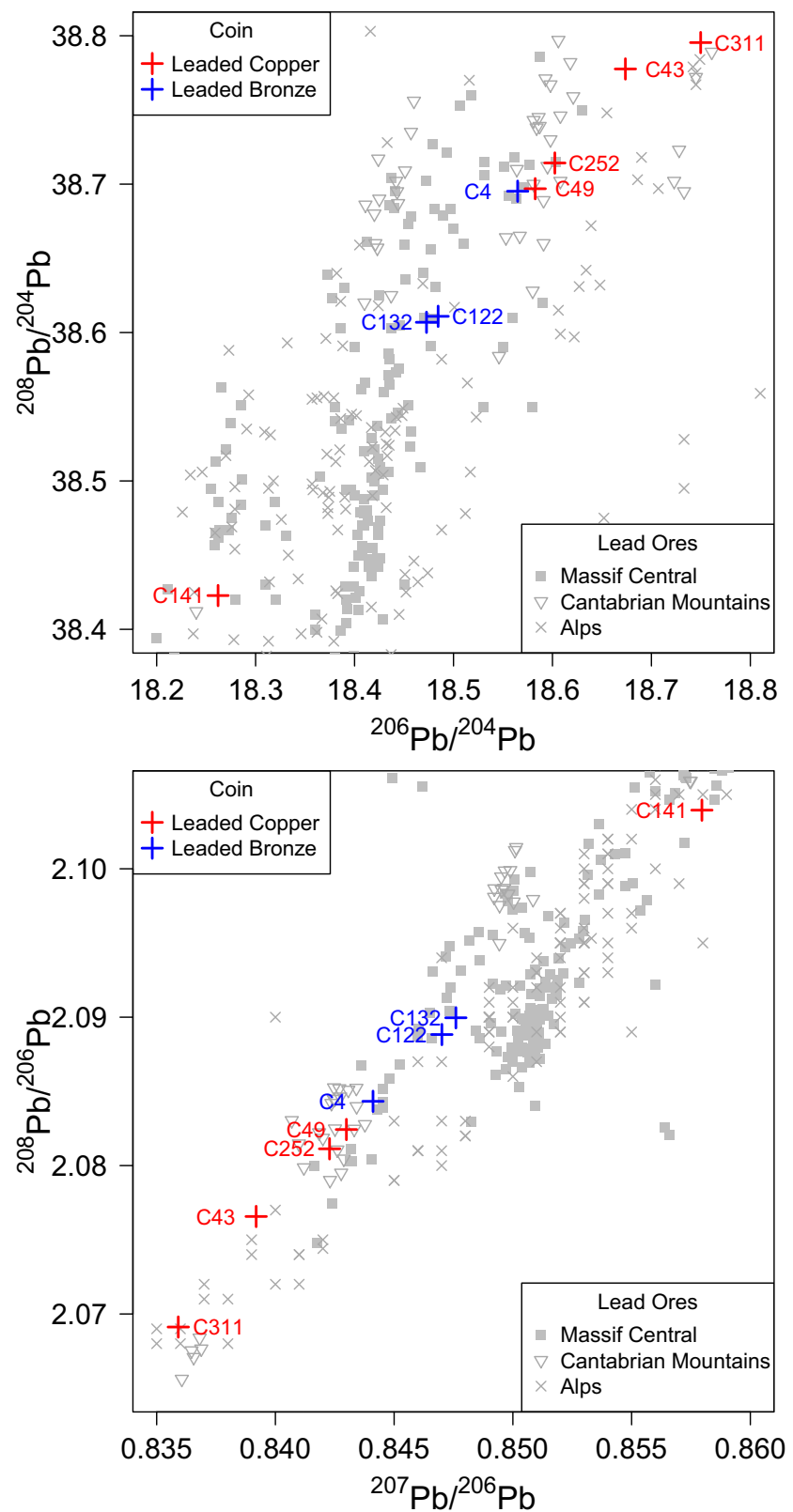

Fig. $11 \mathrm{~Pb}$ isotope diagrams of the leaded copper alloy coins investigated in comparison with literature data of $\mathrm{Pb}$ ores (Stos-Gale and Gale 2009), notably from the Massif Central (Brevart et al. 1982; Le Guen et al. 1991; Baron et al. 2006), Cantabrian Mountains (Velasco et al. 1996) and Alps (Cattin 2008; Cattin et al. 2011)

(457-474 CE), all with $\approx 21-23 \mathrm{wt} \% \mathrm{~Pb}$, which was added to bronzes with $\approx 2-5 \mathrm{wt} \% \mathrm{Sn}$. If these should represent the same nummi minimi of Leo I, they are not only consistent in their alloy composition, but also share similar $\mathrm{Pb}-\mathrm{Pb}$ model ages of $\approx 190-220 \mathrm{Ma}$. The $\mathrm{Pb}$ isotope ratios of the two broadly dated Late Roman nummi minimi are consistent with ores from the Massif Central in France, or from the Valais in the Swiss Alps (Baron et al. 2006; Cattin 2008; Cattin et al. 2011). The Leo I coin is also consistent with ores from the same approximate region, the Massif Central or Cantabrian Mountains (Velasco et al. 1996; Baron et al. 2006).
These results indicate that coinage under Leo I, during the third quarter of the fifth century, may have used a specific alloy recipe for nummi minimi. It also indicates that the lead used to debase the bronze was consistent, in terms of its origin. This is in direct contrast to the first half (Theodosius II) and last quarter (Zeno) of the fifth century, where the amount of lead added to debase the copper was inconsistent $(\approx 5-20 \mathrm{wt} \%$ $\mathrm{Pb}$ ) and the lead metal probably derived from a variety of sources.

\section{The fifth century monetary 'crisis': optimising small change}

Whilst lead lowers the melting point of copper alloys, and up to 2 wt\% can improve casting (Craddock 1979, p. 75), these functional aspects alone are insufficient to explain why it was selectively used for debasing copper coinage during the two episodes identified. A more likely explanation is that it was 'to economise the bronze' (Goussous 1995, p. 203), which would imply a shortage or lack of access to fresh copper metal. This pattern of debasement is more widely associated with precious metal coinage denominations (Butcher 2015), but it appears to be the same for copper (Jones 1953, p. 310). As shown in Table 1, the frequency of coinage during the fourth and fifth centuries $\mathrm{CE}$ from Gerasa/Jerash likely reflects the peak in economic activity in low-cost daily transactions during this period.

An alternative interpretation is that raw material being used to produce the nummi minimi does not represent a deliberate recipe to debase copper with lead, but the recycling of leaded bronze scrap. This is supported by our $\mathrm{Pb}$ isotope results data showing a clear consistency among nummi minimi, indicating the re-melt of large bronzes. It is perhaps no coincidence also that the composition resembles the recipe alloy caldarium, referred to by Pliny (first century CE), the Mappae Clavicula (eighth century CE) and Agricola (sixteenth century), though generally a reference to impure copper used for casting (Dungworth and Nicholas 2004). In Pliny (Book 34, Chapter 20), the recipe can be between 8 and 12 parts $\mathrm{Pb}$ to 100 parts $\mathrm{Cu}$ (roughly 1:10 ratio), and this alloy is brittle, only suitable for castings (Bostock 1855). In contrast, the recipe in the Mappae Calvicula is 1 part $\mathrm{Pb}$ to 4 parts $\mathrm{Cu}$ (Smith and Hawthorne 1974). Both recipes, therefore, produce a broad range of anything between 7 and $20 \mathrm{wt} \% \mathrm{~Pb}$. It is also worth noting that the copper used in these recipes may be a combination of new and 'old' (recycled) copper (alloy). Therefore, it is plausible that the nummi minimi were cast from recycled leaded bronze objects (e.g. statues) or made from fresh lead added to copper (alloy).

Whether or not the nummi minimi represent copper alloys that were subsequently leaded, recycled leaded bronzes, or a combination thereof, the apparent absence of fresh copper base metal suggests a period of limited supply or at least limited access to copper ore. It may also signify a choice to use less fresh copper. This conclusion is further supported by the work of Bijovsky 
(2000, 2012, 2017). She states that 'the economic conditions[...] led to a number of local monetary initiatives' and that whilst 'the minting of bronze coins during the fifth century shows signs of crisis and reduction... the nature of currency itself shows... evidence for creative and extensive 'emergency' monetary activity' (Bijovsky 2000). Some have even referred to this as epidemic coinage (Peter 2011). The diversity of copper alloys represented here for minting nummi minimi are a manifest expression of the creative response needed in the fifth century CE to fulfil the need for everyday small change in the city, and need not necessarily be interpreted as an 'emergency' or 'decline' per se. During a time when official mints were unreliable in issuing fresh coinage, minimi reflect a conscious decision by a locality to facilitate transactions by issuing token-like coinage produced from locally available metals. Thus, the re-use and recycling of locally available copper (alloys) represents an optimisation in the use of these metals for daily life, where the need for small change was vitally necessary. The $\mathrm{Pb}$ isotope results certainly show diversity in the lead being used to debase copper, with the exception of where old bronzes were being re-used. This same pattern of efficient recycling and optimisation was also observed in the glass finds recently analysed from Gerasa/Jerash (Barfod et al. 2018).

The diversity in copper alloys used for minting this small change is therefore indicative of local (some label 'imitative') or regional minting, where standards of coin production were either flexible, not enforced, or unmaintained on a supraregional level. This may help explain why a significant portion of the nummi minimi recovered from the Northwest Quarter of Gerasa/Jerash is devoid of any device. Were they worn smooth, or were they intentionally made as blanks? A recent re-evaluation of this observation has inclined scholars towards the production of blank flans, rather than worn coins, for which the coin finds from Gerasa/Jerash have played a pivotal role in interpretation (Bijovsky 2000). These blank flans which we have confirmed to in fact be minted blanks, were put into circulation alongside minted coinage. Excavations of the so-called Macellum at Gerasa/Jerash provided some 730 unidentifiable nummi minimi (Marot 1998), whilst at Pella there are 515 unidentified specimens (Sheedy et al. 2001), which Bijovsky (Bijovsky 2000) claims are noteworthy proportions that cannot be ignored.

The ceasing of copper issues, on a larger scale, after Theodosius I (395 CE) may have led to copper inflation (Jones 1953, pp. 311-312). The 'blank' nummi minimi, such as that found at Gerasa/Jerash and other sites, may thus represent a local and agreed communal response to a shortage of freshly minted coinage, to facilitate everyday transactions. This may also explain why there was no need to mark them. Being blank may even have helped improve circulation, where locally produced 'marked' coppers may not have been accepted elsewhere. It may also explain why older and heavily worn fourth century nummi minimi stayed in circulation (Bijovsky 2000), essentially disguised amongst the newly minted blank nummi minimi.

\section{‘Abd al-Malik's monetary reform}

The compositional changes in copper coinage are also informative about the organisation of the Umayyad monetary economy and the monetary reform of 'Abd al-Malik in around 696/ 697 CE. The pre-reform fulūs, identified as copper, indicate that the raw metal was accessible and available, and it can be suggested that it derived from the nearby copper mines of Faynan. The use of copper for minting fulüs is a marked change from the copper alloys used for everyday coinage in the previous periods. Though perhaps less so for the leadedcopper used in the Byzantine nummi minimi.

The Roman presence at the nearby copper mines of Faynan can be dated to between the late third to early fifth centuries CE (Weisgerber 2006, p. 18). However, mining operations appear to have ceased when the army withdrew in around the 360s CE (Kind et al. 2005, p. 192). This could explain why copper from this mine was not readily available during the fifth century CE. During the early Islamic period (seventh and eighth centuries $\mathrm{CE}$ ), there is evidence for copper exploitation in the Wadi Arabah, based on radiocarbon dates of slag heaps and domestic housing found at Beer Ora, Timna and also east of Faynan (Weisgerber 2006, pp. 24-25). It is conceivable, therefore that the early Islamic mining activities in the region and the appearance of pure copper coinage are related.

The use of copper alloys, rather than pure copper, to mint post-reform fulüs might be compared to the adoption of copper alloys for minting nummi minimi in the fifth century CE. The reasons for debasing the copper may reflect a conscious decision related to limited access to copper metal or copper ores. Despite this, the post-reform fulüs from three mints in Junds al-Urdunn and Dimashq share similar compositions. This implies that the monetary system was organised by a central administration, who controlled the copper alloy being used to mint coinage.

\section{Conclusions}

The results provided here may combine two systems that sometimes are perceived as being very different regarding religion, politics and culture. It is the transition from Byzantine to Islamic rule (cf: Avni 2014). However, the chronological overview of everyday coinage has the ability to show insights into the wider long-term socio-economic processes from the fourth to the eighth centuries CE. The metallographic, chemical and isotopic study of everyday small change from the Northwest Quarter of Gerasa/Jerash has provided new insights into the copper and copper alloys used in coinage from the fourth to the early eighth centuries CE. The overall results are significant in terms of enhancing our understanding of broader socio-economic developments during this time. 
The chronological developments show that nummi minimi were manufactured from a diverse range of copper alloys in the fifth century CE, and whilst this could relate to wider economic issues, we conclude that this currency is a creative local response to shortages in officially minted coinage. Different copper alloys could be optimally used to produce this small change in order to continue low-value daily transactions in urban life. It is unclear whether these alloys represent specific metal recipes for adding lead to copper base metal, or recycling leaded bronzes, but our work shows that it is very likely that moneyers were recycling metals to meet the shortfall in small change. The copper base metal used for the leaded copper Byzantine nummi minimi appears to be relatively free of 'alloying' components. This indicates that relatively pure copper was accessible again, even though it was still being debased with lead.

Finally, the pre-reform Umayyad coinage shows that pure copper metal was available, but it remains to be shown whether this metal actually originated from the famous copper mines at Faynan or elsewhere in the Arabah. What is clear is that this use of pure copper was short lived. Copper was debased once more to produce the post-reform fulüs. The compositions of the post-reform coinage; however, strongly indicates a central administration in charge of the metal used to mint coinage under the Umayyad Dynasty.

Overall, the longue durée of copper coinage in Gerasa/ Jerash gives us insights into compositional fluctuations and minting technology that are an invaluable addition to our understanding of monetary organisation and small change in the Eastern Mediterranean.

Acknowledgments We would like to thank the Department of Antiquities of Jordan in Amman and Jerash for giving permission to undertake the Danish-German Jerash Northwest Quarter Project and for facilitating and supporting our work. Optical microscopy, micro-XRF analysis and $\mathrm{Pb}$ isotope determinations were undertaken at the Aarhus Geochemistry and Isotope Research (AGIR) Platform in the Department of Geoscience, Aarhus University with the technical assistance of Rikke Brok Jensen (mounting samples), Rasmus Andreasen ( $\mathrm{Pb}$ isotope measurements) and Erin Rosenberg-Andreasen (assistance with some of the $\mathrm{XRF}$ analyses reported). Hardness testing was conducted at the Department of Engineering (NAVITAS), Aarhus University, with the technical assistance of Maryam Zolbin. This work was supported by the Danish National Research Foundation under the grant DNRF119-Centre of Excellence for Urban Network Evolutions (UrbNet), The Carlsberg Foundation, Deutsche Forschungsgemeinschaft, Deutscher PalästinaVerein, the EliteForsk initiative of the Danish Ministry of Higher Education and Science and H. P. Hjerl Hansens Mindefondet for Dansk Palæstinaforskning. We are grateful to the anonymous reviewers for their helpful comments and advice.

Open Access This article is distributed under the terms of the Creative Commons Attribution 4.0 International License (http:// creativecommons.org/licenses/by/4.0/), which permits unrestricted use, distribution, and reproduction in any medium, provided you give appropriate credit to the original author(s) and the source, provide a link to the Creative Commons license, and indicate if changes were made.

\section{References}

al-Sa'ad Z, Affaneh S, Hatamleh M (2000) Scientific analysis of a collection of Nabatean and Roman copper-based coins excavated from Wadi Mousa. Jordan Yarmouk Numis 12:19-38

al-Sa'ad Z, Goussous N (1997) Scientific analysis of a collection of early Ummayad copper-based coins of Bilad al-Sham. Yarmouk Numis 9: 19-38

Avni G (2014) The Byzantine-Islamic transition in Palestine. An archaeological approach. Oxford University Press, Oxford

Baldi E (2014) Coinage of the Ostrogoths in the British Museum (Online Research Catalogue)

Barfod GH, Freestone IC, Lichtenberger A, Raja R, Schwarzer H (2018) Geochemistry of Byzantine and early Islamic glass from Jerash, Jordan: typology, recycling, and provenance. Geoarchaeology. 33: 623-640. https://doi.org/10.1002/gea.21684

Baron S, Carignan J, Laurent S, Ploquin A (2006) Medieval lead making on Mont-Lozère massif (Cévennes-France): tracing ore sources using $\mathrm{Pb}$ isotopes. Appl Geochem 21:241-252. https://doi.org/10. 1016/j.apgeochem.2005.09.005

Begemann F, Hauptmann A, Schmitt-Strecker S, Weisgerber G (2010) Lead isotope and chemical signature of copper from Oman and its occurrence in Mesopotamia and sites on the Arabian Gulf coast. Arab Archaeol Epigr 21:135-169. https://doi.org/10.1111/j.16000471.2010.00327.x

Bijovsky G (2017) The coins. In: Greenberg R, Tal O, Da'adli T (eds) Bet Yerah. Volume III, Hellenistic philoteria and Islamic al-Sinnabra: the 1933-1986 and 2007-2013 excavations. Israel Antiquities Authority, Jerusalem

Bijovsky G (2012) Gold coin and small change: monetary circulation in fifth-seventh century Byzantine Palestine. EUT Edizioni Università di Trieste, Trieste

Bijovsky G (2000) The currency of the fifth century C.E. in Palestine some reflections in light of the numismatic evidence. Israel Numismatic J 14:196-210

Boni M, Koeppel V (1985) Ore-lead isotope pattern from the IglesienteSulcis area (SW Sardinia) and the problem of remobilization of metals. Mineral Deposita 20:185-193. https://doi.org/10.1007/ BF00204563

Bostock J (1855) The natural history. Pliny the elder. Taylor and Francis, London

Brevart O, Dupre B, Allegre CJ (1982) Metallogenic provinces and the remobilization process studied by lead isotopes; lead-zinc ore deposits from the southern massif central, France. Econ Geol 77:564 575. https://doi.org/10.2113/gsecongeo.77.3.564

Butcher K (2015) Debasement and the decline of Rome. In: Bland R, Calomino D (eds) Studies in ancient coinage in honor of Andrew Burnett. SPINK, London, pp 181-205

Canovaro C, Asolati M, Calliari I, Bonetto J (2015) Analisi metallografica di monete bronzee tardo imperiali scavate ad Aquileia. Metall Ital 9:43-48

Canovaro C, Calliari I, Asolati M, Grazzi F, Scherillo A (2013) Characterization of bronze Roman coins of the fifth century called nummi through different analytical techniques. Appl Phys A Mater Sci Process 113:1019-1028. https://doi.org/10.1007/s00339-013$7730-3$

Cattin F (2008) Modalités d'approvisionnement et modalités de consommation du cuivre dans les Alpes au 3e millénaire avant notre ère : apport des analyses métalliques à la connaissance des peuplements du Néolithique final, du Campaniforme et du Bronze ancien. Université de Genève

Cattin F, Guénette-Beck B, Curdy P, Meisser N, Ansermet S, Hofmann B, Kündig R, Hubert V, Wörle M, Hametner K, Günther D, Wichser A, Ulrich A, Villa IM, Besse M (2011) Provenance of early bronze age metal artefacts in Western Switzerland using elemental and lead 
isotopic compositions and their possible relation with copper minerals of the nearby Valais. J Archaeol Sci 38:1221-1233. https://doi. org/10.1016/j.jas.2010.12.016

Craddock PT (1979) The copper alloys of the medieval Islamic world inheritors of the classical tradition. World Archaeol 11:68-79

Domergue C (2008) Les Mines Antiques. La production des métaux aux époques grecque et romaine, Paris

Dungworth D, Nicholas M (2004) Caldarium? An antimony bronze used for medieval and post-medieval cast domestic vessels. Hist Metall 38:24-34

Durali-Mueller S, Brey GP, Wigg-Wolf D, Lahaye Y (2007) Roman lead mining in Germany: its origin and development through time deduced from lead isotope provenance studies. J Archaeol Sci 34: 1555-1567. https://doi.org/10.1016/j.jas.2006.11.009

Goodwin T, Gyselen R (2015) Arab byzantine coins from the Irbid hoard. Royal Numismatic Society, London

Goussous NG (1995) Umayyad copper-based coins of Bilad Al-Sham: an analytical and chemical study. Masters thesis, Yarmouk University

Grierson P (1999) Byzantine Coinage. Dumbarton Oaks Research Library and Collection, Washington D. C

Hauptmann A (2007) The archaeometallurgy of copper: evidence from Faynan, Jordan. Springer, Berlin, New York

Hauptmann A, Begemann F, Heitkemper E et al (1992) Early copper produced at Feinan, Wadi Araba, Jordan: the composition of ores and copper. Archeomaterials 6:1-33

Hohlfelder RL (1973) A sixth century hoard from Kenchreai, Hesperia. J Am Sch Class Stud Athens 42:89-101. https://doi.org/10.2307/147471

Hoover OD (2005) Review: small change in Ancient Beirut. Am Numis Soc Mag Winter 2005:304

Jones AHM (1953) Inflation under the Roman empire. Econ Hist Rev 5: 293-318. https://doi.org/10.2307/2591810

Kind HD, Gilles KJ, Hauptmann A, Weisgerber G (2005) Coins from Faynan, Jordan. Levant 37:169-195. https://doi.org/10.1179/lev. 2005.37.1.169

King CE, Metcalf D, Northover JP (1992) Copper-based alloys of the fifth century. Revue Numismatique 6:54-76. https://doi.org/10. 3406/numi.1992.1974

Klein S, Domergue C, Lahaye Y et al (2009) The lead and copper isotopic composition of copper ores from the Sierra Morena (Spain). J Iber Geol 35:59-68

Klose DM (2006) Nummus. Brill's New Pauly 9

Kraeling CH (ed) (1938) Gerasa. City of the Decapolis. American Schools of Oriental Research, New Haven

Le Guen M, Orgeval J-J, Lancelot J (1991) Lead isotope behaviour in a polyphased $\mathrm{Pb}-\mathrm{Zn}$ ore deposit: Les Malines (Cévennes, France). Mineral Deposita 26:180-188. https://doi.org/10.1007/BF00209256

Lichtenberger A, Raja R (eds) (2018) The Archaeology and History of Jerash. 110 Years of Excavations. Brepols, Turnhout

Lichtenberger A, Raja R (eds) (2017) Gerasa/Jerash. From the urban periphery. Suntryk, Aarhus

Ludwig KR, Vollmer R, Turi B et al (1989) Isotopic constraints on the genesis of base-metal ores in southern and central Sardinia. Eur J Mineral 1:10

Marot T (1998) Las Monedas del Macellum de Gerasa (Ŷaraš, Jordania). Aproximación a la circulación monetaria en la provincia de "Arabia." Museum Casa de la Moneda, Madrid

Miles GC (1950) The coinage of the Umayyads of Spain - part one. The American Numismatic Society, New York

Oddy A (2015) The phase 2 coinage of Scythopolis under Mu'awiya and his successors. In: Oddy A, Schulze I, Schulze W (eds) Coinage and history in the seventh century near east, vol 4. Archetype, London, pp 151-178

Pernicka E, Begemann F, Schmitt-Strecker S, Wagner GA (1993) Eneolithic and early bronze age copper artefacts from the Balkans and their relation to Serbian copper ores. Praehistorische Z 68:1-54

Peter M (2011) Von Betrug bis Ersatzkleingeld - Falschmünzerei in römischer Zeit. In: Reuter M, Schiavone R (eds) Gefährliches
Pflaster Kriminalität im Römischen Reich. Landschaftsverband Rheinland, LVR-Archäologischer Park Xanten / LVRRömerMuseum, pp 107-119

Qedar S (1985) A hoard of monetary reform Fulus. Israel Numismatic J 8:65-75

Schindel N (2006) A hoard of Umayyad copper coins from Baysān. Numismatic Chronicle 166:385-392

Schulze I, Schulze W (2018) Working with coins in Jerash: problems, solutions, and preliminary results. In: Lichtenberger A, Raja R (eds) 110 years of excavations in Jerash, Jerash Papers 1. Brepols, Turnhout, pp 195-206

Scuotto M, Bassi C, Lezzerini M, Grifoni E, Legnaioli S, Lorenzetti G, Pagnotta S, Palleschi V (2014) X-ray fluorescence analysis on a group of coins from the ancient roman city of Tridentum (Trento, Italy). X-Ray Spectrom 43:370-374. https://doi.org/10.1002/xrs.2567

Sheedy K, Carson R, Walmsley A (2001) Pella in Jordan 1979-1990. The coins. Adapa: Publications of the Near Eastern Archaeology Foundation, Sydney

Smith CS, Hawthorne JG (1974) Mappae Clavicula: a little key to the world of medieval techniques. Trans Am Philos Soc 64:1-128. https://doi.org/10.2307/1006317

Stacey JS, Kramers JD (1975) Approximation of terrestrial lead isotope evolution by a two-stage model. Earth Planet Sci Lett 26:207-221. https://doi.org/10.1016/0012-821X(75)90088-6

Stos-Gale Z, Gale NH (1992) New light on the provenience of the copper Oxhide ingots found on Sardinia. In: Tykot RH, Andrews TK (eds) Sardinia in the Mediterranean: a footprint in the sea. Sheffield, pp 317-346

Stos-Gale ZA, Gale NH (2009) Metal provenancing using isotopes and the Oxford archaeological lead isotope database (OXALID). Archaeol Anthropol Sci 1:195-213. https://doi.org/10.1007/ s12520-009-0011-6

Stos-Gale ZA, Gale NH, Annetts N et al (1998) Lead isotope data from the Isotrace laboratory, Oxford: Archaeometry Data Base 5, ores from Bulgaria. Archaeometry 40:217-226. https://doi.org/10.1111/ j.1475-4754.1998.tb00834.x

Stos-Gale ZA, Maliotis G, Gale NH, Annetts N (1997) Lead isotope characteristics of the Cyprus copper ore deposits applied to provenance studies of copper Oxhide ingots. Archaeometry 39:83-123. https://doi.org/10.1111/j.1475-4754.1997.tb00792.x

Treadwell L (2015) Symbolism and meaning on the early Islamic copper coinage of Greater Syria. In: Oddy A, Schulze I, Schulze W (eds) Coinage and history in the Seventh Century Near East 4. Archetype, pp 73-95

Valera PG, Valera RG, Rivoldini A (2005) Sardinian ore deposits and metals in the bronze age. In: Lo Schiavo F, Giumlia-Mair A, Sanna U, Valera RG (eds) Archaeometallurgy in Sardinia: from the origins to the beginning of the Early Iron Age. Montagnac, pp 43-88

Velasco F, Pesquera A, Herrero JM (1996) Lead isotope study of Zn-Pb ore deposits associated with the Basque-Cantabrian basin and Paleozoic basement, northern Spain. Mineral Deposita 31:84-92. https://doi.org/10.1007/BF00225398

Wagner GA, Pernicka E, Seeliger TC et al (1985) Geologische Untersuchungen zur frühen Metallurgie in NW-Anatolien. Bull Mineral Res Explor Inst Turk 101:45-81

Weisgerber G (2006) The mineral wealth of ancient Arabia and its use I: copper mining and smelting at Feinan and Timna - comparison and evaluation of techniques, production, and strategies. Arab Archaeol Epigr 17:1-30. https://doi.org/10.1111/j.1600-0471.2006.00253.x

Publisher's note Springer Nature remains neutral with regard to jurisdictional claims in published maps and institutional affiliations. 